Review

\title{
Molecular Link between Vitamin D and Cancer Prevention
}

\author{
Meis Moukayed ${ }^{1}$ and William B. Grant ${ }^{2, *}$
}

1 School of Arts and Sciences, American University in Dubai, P. O. Box 28282, Dubai, UAE; E-Mail:mmoukayed@hotmail.com

2 Sunlight, Nutrition, and Health Research Center, San Francisco, CA 94164-1603, USA

* Author to whom correspondence should be addressed; E-Mail: wbgrant@infionline.net; Tel.: +1-415-409-1980.

Received: 7 August 2013; in revised form: 11 September 2013 / Accepted: 18 September 2013 / Published: 30 September 2013

\begin{abstract}
The metabolite of vitamin D, 1 $\alpha, 25$-dihydroxyvitamin $\mathrm{D}_{3}$ (also known as calcitriol), is a biologically active molecule required to maintain the physiological functions of several target tissues in the human body from conception to adulthood. Its molecular mode of action ranges from immediate nongenomic responses to longer term mechanisms that exert persistent genomic effects. The genomic mechanisms of vitamin D action rely on cross talk between $1 \alpha, 25$-dihydroxyvitamin $\mathrm{D}_{3}$ signaling pathways and that of other growth factors or hormones that collectively regulate cell proliferation, differentiation and cell survival. In vitro and in vivo studies demonstrate a role for vitamin D (calcitriol) in modulating cellular growth and development. Vitamin D (calcitriol) acts as an antiproliferative agent in many tissues and significantly slows malignant cellular growth. Moreover, epidemiological studies have suggested that ultraviolet-B exposure can help reduce cancer risk and prevalence, indicating a potential role for vitamin D as a feasible agent to prevent cancer incidence and recurrence. With the preventive potential of this biologically active agent, we suggest that countries where cancer is on the rise-yet where sunlight and, hence, vitamin D may be easily acquired-adopt awareness, education and implementation strategies to increase supplementation with vitamin D in all age groups as a preventive measure to reduce cancer risk and prevalence.
\end{abstract}

Keywords: vitamin D; cancer; mechanisms; ecological studies; observational studies; prevention; animal models 


\section{Abbreviations}

WSTF: Williams syndrome transcription factor; WINAC: WSTF including nucleosome assembly complex; MCF-7: Michigan Cancer Foundation-7 human breast adenocarcinoma cell line; MART-10: 19-nor-2 $\alpha$-(3-hydroxypropyl)-1 $\alpha, 25$-Dihydroxyvitamin $\mathrm{D}_{3}$; EB1089: Seocalcitol; SW620: Human colorectal adenocarcinoma cell line; PC/JW: Human colorectal adenoma-derived epithelial cell line derived from adenomatous polyposis; HT29: Human colorectal adenocarcinoma cell line HT29; SW-480-ADH: malignant colon cancer subline of human Dukes' type B colorectal adenocarcinoma cell line SW-480; LNCaP: Human prostatic carcinoma cell line LNCaP; CL-1: Human prostate cancer cell line derived from LNCaP; IGFBP3: IGF-binding protein 3; MCF10CA: Human metastatic breast cancer cell line MCF10CA; HL60: Human promyelocytic leukemia cells; mTOR: mammalian target of rapamycin; CDK: Cyclin-dependent kinase; APC: Adenomatous polyposis coli; LPB-Tag: Long Probasin Promoter-Large T Antigen.

\section{Vitamin D: Introduction, Function and Metabolism}

\subsection{Introduction to Vitamin D: History and Physiological Roles}

Vitamin D refers to two fat soluble substances, vitamin $\mathrm{D}_{3}$ (cholecalciferol) and vitamin $\mathrm{D}_{2}$ (ergocalciferol), and their metabolites, which are considered to be important nutrients for human health. Dietary vitamin $\mathrm{D}_{3}$ sources include dairy, eggs, fish and meat [1], while dietary vitamin $\mathrm{D}_{2}$ (ergocalciferol) sources are UVB-irradiated yeast and fungi [2,3]. However, there seem to be some unaccounted for dietary sources [4]. In humans, vitamin $\mathrm{D}_{3}$, made naturally by the body following exposure to ultraviolet light, acts as an important endocrine hormone precursor.

Mellanby [5] and McCollum [6] first identified vitamin D's effects in experiments that investigated the chemical components of cod liver oil that could prevent rickets in animals. Later studies by Hess [7], McCollum [8], Steenbock [9], Askew [9] and Windaus [10] helped isolate, identify and determine the structure and function of this hormone and its essential role in skeletal health. In 1939, Windhaus determined the structure and initial pathways by which vitamin $\mathrm{D}_{3}$ was synthesized from 7-dehydrocholesterol [11,12]. His biochemical investigations were the basis for Holick and colleagues [13-16] to later elucidate the biochemical pathways and physiological mechanisms that

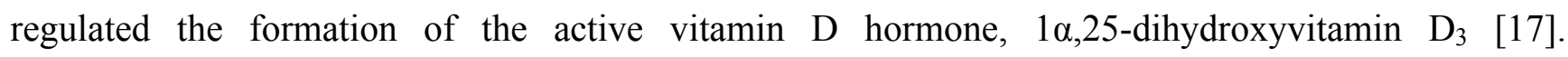
Vitamin $D_{3}$ is initially synthesized via the initial conversation of 7-dehydrocholesterol upon UV irradiation of the skin [13-16]. This provitamin $\mathrm{D}_{3}$ is further metabolized in the liver and kidneys to produce the active hormone, $1 \alpha, 25$-dihydroxyvitamin $\mathrm{D}_{3}$, often mentioned in the literature simply as vitamin D [18-21] (Figure 1). However, extrarenal production of 1,25-dihydroxyvitamin D also occurs in many organs [22]. 25-hydroxyvitamin $\mathrm{D}[25(\mathrm{OH}) \mathrm{D}]$ is the circulating metabolite of vitamin $\mathrm{D}$ that is routinely measured.

In the 90 years since the above discovery to date, scientists have demonstrated unequivocally that vitamin D exerts a spectrum of biological effects well beyond its classical role in calcium and phosphate homeostasis. The cloning of the vitamin D receptor (VDR) in 1987 and the detection of VDRs in almost all tissues of the body spurred wide interest in its physiological functions [23]. Vitamin $\mathrm{D}_{3}$ has important homeostatic functions in fetal and adult development and differentiation in 
endocrine, metabolic, neurological, epidermal and immunological systems of the human body [24-26] (Table 1). Moreover, several studies support an essential role for vitamin D in regulating mechanisms controlling cell proliferation, differentiation and growth. These bodies of evidence reveal protective functions for vitamin D against carcinogen-induced neoplasia and recurrent secondary metastasis [27].

Table 1. Vitamin D can exert its action in several organ systems and tissues of the body. This occurs in a paracrine, autocrine, intracrine or endocrine manner [24-26].

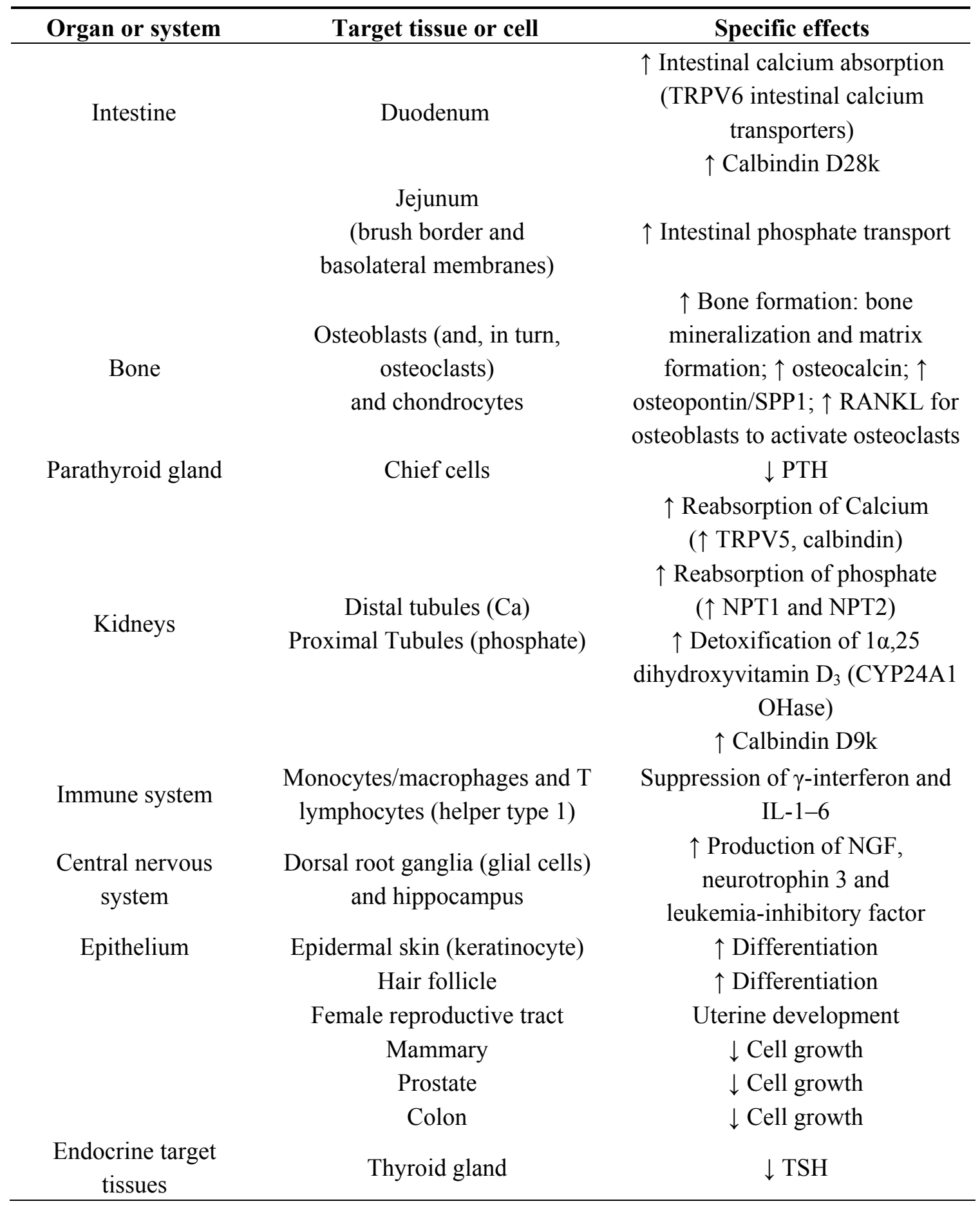


Table 1. Cont.

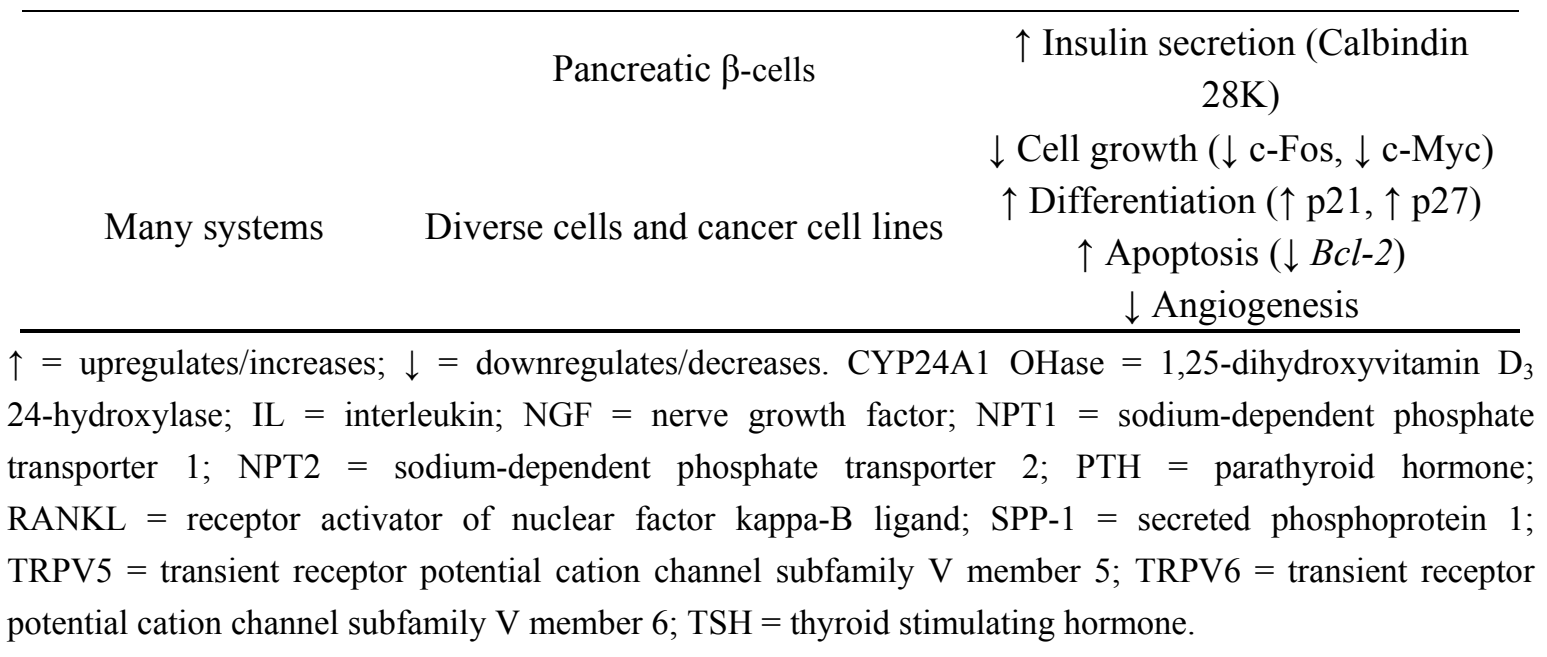

Figure 1. Ultraviolet radiation $(290-330 \mathrm{~nm})$ from the sun and body heat convert 7-dehydrocholesterol in the skin to cholecalciferol (vitamin $\mathrm{D}_{3}$ ). Vitamin $\mathrm{D}_{3}$ is further metabolized in the liver and kidneys to yield the active metabolite $1,25(\mathrm{OH})_{2} \mathrm{D}_{3}$.

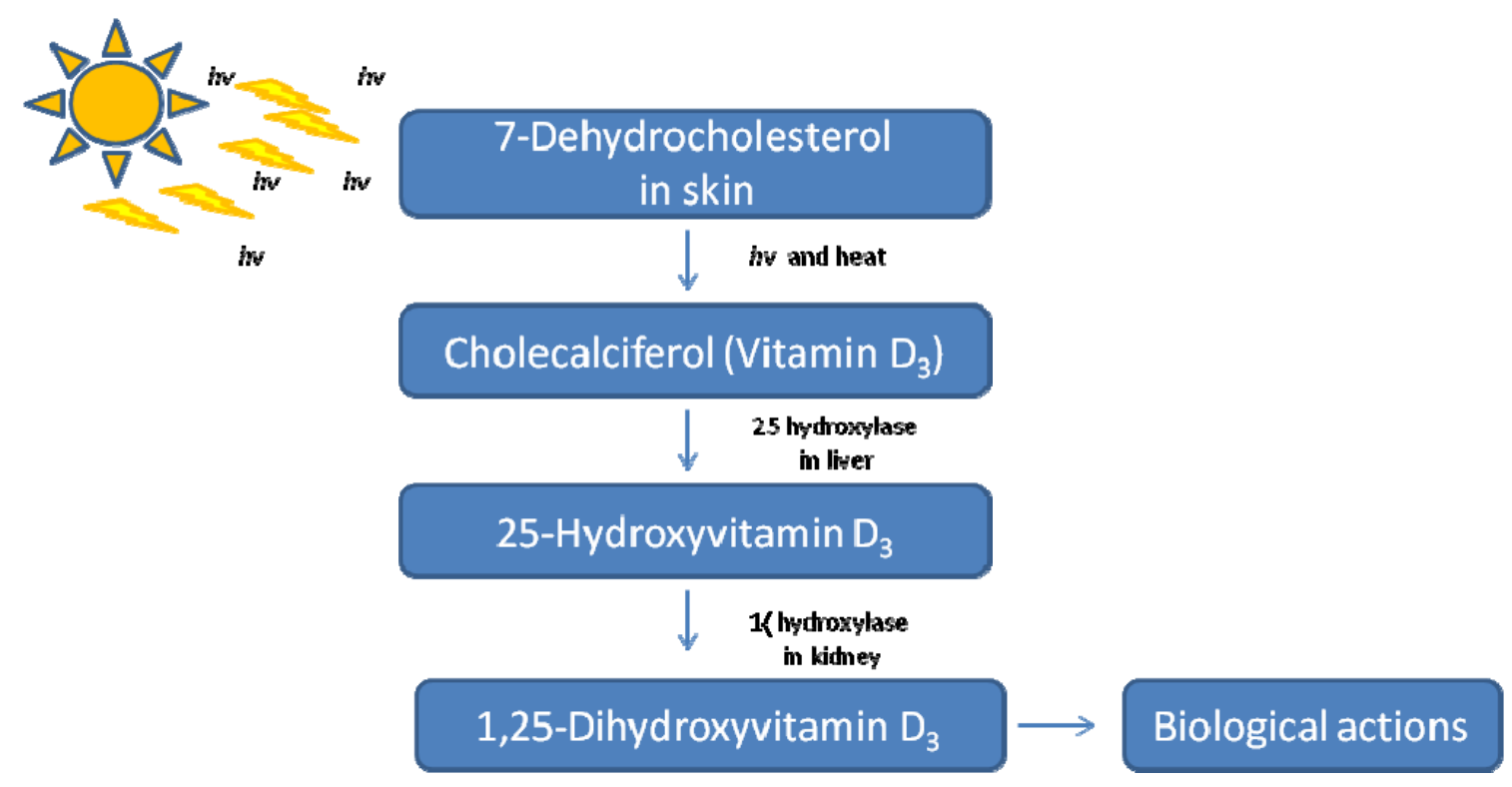

\subsection{Vitamin D Genomic Action via the VDR}

\subsubsection{VDR Distribution, Dimerization and Function}

Vitamin $\mathrm{D}$ acts as a steroid hormone by regulating gene transcription. The effect of the bioactive hormone 1 $\alpha, 25$-dihydroxyvitamin $\mathrm{D}_{3}$ occurs via the VDR. The VDR was identified in 1969 [28] and was cloned in 1987 [29]; its crystal structure and binding to its natural ligand were characterized in 2000 [30]. Since its discovery, researchers have detected the VDR in many tissues of the body, including bone, pancreatic $\beta$ cells, parathyroid gland, brain, skin, prostate, testes, heart, skeletal muscle tissue, breast, liver, lung, intestine, kidneys, adipose cells and immune response cells, such as macrophages, dendritic cells and activated B- and T-cells [31-36]. The receptor is widely distributed in the body, indicating physiological roles in homeostatic regulation beyond bone tissue 
mineralization. Ligand binding by $1 \alpha, 25$-dihydroxyvitamin $\mathrm{D}_{3}$ to its receptor can either activate or repress genes [37-41]. The VDR exerts its genomic effects by binding to regulatory vitamin D response elements (VDREs) present in the promoter regions of target genes in these tissues. The most prevalent motif for the VDRE sequence consists of two half-sites, each with the six-nucleotide consensus sequence, GGTCCA, separated by three other nucleotides of any sequence [37]. This motif is known as direct repeat 3 (DR3), although other configurations of VDRE-binding sites, including DR6 and DR4, exist in some vitamin D-regulated genes [26,37,42,43].

Ligand-bound VDR-dependent transcription regulation of genes occurs via the dimerization of the receptor with the retinoic $X$ receptor (RXR). Although VDR preferentially binds to RXR, creating a VDR-RXR dimer, VDR can also bind other receptors of the nuclear receptor superfamily, which include thyroid, vitamin A, PPAR- $\gamma$ and other orphan receptors [44]. The VDR-RXR dimer can regulate genes in several systems and tissues [26].

\subsubsection{VDR Structure and Role of Cofactors}

The VDR has two variant isoforms, one with 424 amino acids (aa) and the other with 427 aa [45,46]. The complete functional protein contains several distinct domains: a DNA-binding domain (aa 24-115), a nuclear localization sequence (aa 44-55, 79-105), a hinge domain (aa 116-226), a dimerization domain (aa 37, 91-92, 244-263, 317-395) that overlaps with the ligand-binding domain (LBD) (aa 227-244, 268-326, 396-422) and the sequences of the activation domain (AF2; aa 246, 416-422) [47,48].

As with other nuclear hormone receptors, VDR has a conserved DNA-binding domain that comprises two zinc fingers necessary for target gene VDRE binding and dimerization of the activated receptor. The first zinc finger (proximal to the $\mathrm{N}$ terminus of the protein) is required for docking at the VDRE, whereas the second zinc finger is required for binding dimerization with RXR. A nuclear localization sequence is located within the DNA-binding region and just upstream of the $C$ terminal to this binding domain. The nuclear localization sequence directs localization of the activated receptor to the nucleus to regulate gene transcription. The LBD, which consists of $12 \alpha$-helices joined by $\beta$-sheets, has regions required for 1 $\alpha, 25$-dihydroxyvitamin $\mathrm{D}_{3}$ binding at helix 2 and two further regions required for RXR heterodimerization (see [30,37] for key references on LBD crystal structure and properties and functions). Within this $C$-terminus region of the LBD lies the major activation domain, AF2, required for transcription coactivation. Ligand binding by the active hormone creates a conformational change that releases transcription repressors such as WSTF and WINAC and enables attachment of coactivators [49-51]. AF2 is bound by cofactors of the steroid receptor coactivator (SRC) family, $\mathrm{NCoA} 62-\mathrm{SKIP}, \mathrm{CBP} / \mathrm{p} 300$ and $\mathrm{p} / \mathrm{CAF}$, and proteins of the VDR-interacting protein complex (DRIP/Mediator) [52,53]. CBP/p300 and p/CAF have histone acetyl transferase ability, which unravels the chromatin of the target gene [54]. This unwinding of the chromatin enables the transcription machinery, such as TF2B and RNA polymerase II, to bind and subsequently initiate transcription [55]. The DRIP complex, made up of approximately 15 leucine-rich proteins, is unique in its function in that it creates a bridge between the SRC coactivator proteins lodged at the VDRE of the gene and the transcription machinery at the start site of the regulated gene. DRIP 205 specifically is required in this 
vitamin D-induced transcription activation to enable an open position of the transcribed chromatin [56,57].

\subsubsection{Nongenomic Cytoplasmic Action}

Vitamin D can also function via nongenomic mechanisms without exerting transcriptional effects or requiring additional protein synthesis. Such nongenomic effects have previously been reported for other nuclear hormones, such as estrogen, thyroid hormone and corticosteroids $[58,59]$. Vitamin D is thought to regulate rapid cellular calcium flux and calcium-activated chloride channel activity via a membrane-bound receptor protein known as 1,25-(OH) $)_{2} \mathrm{D}$ membrane-associated rapid response steroid-binding protein (1,25 D-MARRSBP), also known as endoplasmic reticulum stress protein 57. MARRSBP was identified, purified and cloned from chick intestinal epithelium [60]. MARRSBP has also been found in tissues, including osteoblasts, liver, adipocytes and muscle [61-67]. MARRSBP acts via a $\mathrm{G}$ protein-coupled process that activates phospholipase $\mathrm{C}$. Phospholipase $\mathrm{C}$ hydrolyzes membrane-bound phosphoinositol bisphosphate $\left(\mathrm{PIP}_{2}\right)$ to release inositol trisphosphate $\left(\mathrm{IP}_{3}\right)$ and diacylglycerol. In turn, these cellular messengers enable the release of calcium from endoplasmic stores and mediate the acute quick release of calcium in the cell [68]. This interaction, however, cannot occur without nuclear-targeted VDR, indicating that a cooperative mechanism of action between membrane-bound MARRSBP and VDR mediates rapid responses in some tissue types $[35,69]$. This interaction between the membrane-bound and nucleus-bound receptors can occur in cancer cell lines. In MCF-7 breast cancer cells, MARRSBP antagonizes VDR, thus implicating the membrane-bound MARRSBP in the modulation of cellular proliferation and malignancy. However, the full purpose of this interaction is yet to be elucidated [70].

\section{Vitamin D and Cancer}

\subsection{Vitamin D Mechanisms Regulating Cellular Proliferation and Growth}

Through the genomic actions of vitamin $\mathrm{D}_{3}$ via VDR regulation of several genes containing VDREs, $1 \alpha, 25(\mathrm{OH})_{2}$ vitamin $\mathrm{D}_{3}$ and its analogues inhibit cell cycle progression and tumor cell growth in several cancer cell lines. Such mechanisms range from preventing cell proliferation (cell cycle arrest) to inducing apoptosis to inducing or suppressing cell adhesion molecules and growth factors that promote cellular homing and metastasis.

\subsection{Cell Cycle and Apoptosis}

The cell cycle is regulated by a complex network of interlinked regulators that in concert govern cellular proliferation. Vitamin D may exert growth inhibitory effects through repression of different key molecules involved in cell cycle regulation. For example, Jensen and colleagues [71] demonstrated that $1, \mathrm{a}, 25-(\mathrm{OH})_{2} \mathrm{D}_{3}$ treatment of human breast cancer cell line MCF-7 resulted in repression of c-Myc, a known proto-oncogene in the cell cycle regulatory machinery. Salehi-Tabar and colleagues [72] demonstrated that $1, \mathrm{a}, 25-(\mathrm{OH})_{2} \mathrm{D}_{3}$ can suppress expression of the oncogene c-Myc and, thus, promotes the increased expression of its antagonist, the transcriptional repressor, MAD1/MXD1. This effect is mediated by other cellular regulators, such as F-box protein (FBW7). Meyer and colleagues [73] also 
demonstrated that in colonic cells of colorectal tumors, treatment with 1,a,25- $(\mathrm{OH})_{2} \mathrm{D}_{3}$ can suppress c-Fos and c-Myc gene expression in a manner that involves B-catenin signaling interactions. In prostate cancer cells, Washington and colleagues [74] showed that this repression is independent of retinoblastoma protein $(\mathrm{Rb})$. Li and colleagues [75] showed that treatment of ovarian cancer cells with 1,25-dihydroxyvitamin $\mathrm{D}_{3}$ results in $\mathrm{p} 27$ (Kip1) stabilization and $\mathrm{G}(1)$ arrest through downregulation of cyclin E/cyclin-dependent kinase 2 and Skp1-Cullin-F-box protein/Skp2 ubiquitin ligase. Collectively, these studies confirm that vitamin D can suppress cell proliferation through inhibitory effects on several regulators in the network of cell cycle control machinery.

Akutsu and colleagues [76] reported that treating human head and neck squamous cell carcinoma cells SCC25 with vitamin D arrested cell proliferation at the $G_{0} / G_{1}$ phase. Vitamin $D$ also upregulated the growth-arrest DNA damage repair factor, GADD45 $\alpha$, at both the mRNA and protein levels. Cyclin-dependent kinase inhibitor p21 was also induced at the mRNA level, but not at the protein level. Chiang and colleagues showed that both vitamin D and its analogue, MART-10, were potent chemicals that could arrest the cell cycle at the $\mathrm{G}_{0} / \mathrm{G}_{1}$ transition phase in MCF-1 breast cancer cell lines. This process occurred through the expression of BAX/BCL proapoptotic proteins and the initiation of apoptosis via release of cytochrome $\mathrm{C}$ from mitochondria. Moreover, MART-10 induced no observed hypercalcemic effects (which are sometimes observed with vitamin D treatment), suggesting that such analogues would be good agents to deter cancer progression without detrimental side effects ([77]). In adenoma and carcinoma colorectal cell lines (SW620, PC/JW and HT29), treatment with vitamin D or its analogue, EB1089, induced apoptosis independent of p53, increased the number of cells in the $\mathrm{G}_{1}$ phase and increased levels of the proapoptotic protein, Bak (a member of the $\mathrm{BCl}$-2 gene family), in all cell lines tested. This finding suggested that vitamin D and its analogues are clinically effective for treating colorectal cancers. In rat glioma C6.9 cell lines, vitamin D treatment induced apoptosis via DNA fragmentation and upregulation of $p 53$ and GADD45 genes [78]. In prostate cancer cell lines, vitamin $\mathrm{D}$ treatment inhibited cyclin-dependent kinase 2 activity and induced $\mathrm{G}_{0} / \mathrm{G}_{1}$ cell cycle arrest [79]. Therefore, several lines of evidence from in vitro studies support the role of vitamin D in promoting cell cycle arrest and promoting apoptosis in malignant transformed cells.

\subsection{Hypoxia, Oxidative Stress, HIF-1 and Angiogenesis}

Hypoxia and oxidative stress are often associated with cancer progression. Oxidative stress often induces DNA damage and loss of DNA-repair ability [80,81]. Hypoxia also promotes hypoxia-inducible factor 1 (HIF-1)-dependent angiogenesis essential for tumor growth [82]. Treatment of several cell lines, such as SW-480-ADH, LNCaP (a prostate cancer cell line) and MCF-7, with vitamin D activates cellular signaling cascades that reduce thioredoxin and promote antioxidant responses, induce mRNA expression of superoxide dismutase (in prostate epithelial cells) and downregulate glutathione levels by increasing glucose-6-phosphate dehydrogenase expression [83-85].

Vitamin $\mathrm{D}_{3}$ inhibits initiators of cellular angiogenesis in several cancer cell lines. Adding vitamin $\mathrm{D}_{3}$ to the highly aggressive androgen-insensitive prostate cancer cell line, CL-1, inhibits proliferation of these cells both in normoxia and in hypoxic environments that resemble those in cancer tissues. This effect is also observed in LNCaP and in SW-480 colon cancer cell lines. Vitamin $\mathrm{D}_{3}$ also inhibits secretion of vascular endothelial growth factor (VEGF) in these cell lines, as well as in the MCF-7 
breast cancer cell line. Furthermore, vitamin D treatment downregulates endothelin 1 (ET-1) and glucose transporter 1 (Glut-1). VEGF-1, ET-1 and Glut-1 are essential for inducing angiogenesis. This molecular effect is mediated via significant downregulation of HIF-1 transcription and translation [86].

A study by Chung and colleagues [87] showed that in tumor-derived endothelial cells from VDR knockout mice, loss of VDR resulted in an increase in HIF-1 $\alpha$, VEGF, angiopoietin 1 and platelet-derived growth factor levels. Moreover, in vivo, mice lacking VDR exhibited enlarged blood vessels to perfuse tumor lesions. This clearly implicates VDR in the control of tumor-associated angiogenesis.

\subsection{Interactions with Growth Factors that Mediate Transformation, Cell Adhesion and Metastasis}

Vitamin $\mathrm{D}_{3}$ strongly inhibits the Sonic Hedgehog signaling cascade in human renal cell carcinoma. Mice xenografted with renal cell carcinoma cells yet treated with vitamin D exhibit the absence of tumor development or substantial growth inhibition, suggesting the vitamin $D_{3}$ can be used prophylactically to prevent tumor development or regression [88].

Insulin-like growth factors (IGFs) and their binding proteins have been implicated in the development of several tumors [89]. In prostate cancer, for example, IGFBP3 protein levels decrease when cells progress from benign to malignant metastasis [90,91]. Microarray analysis has shown that vitamin $\mathrm{D}_{3}$ regulates IGFBP3, which sequesters and modulates levels of IGF-I, in LNCaP human prostate cancer cell lines [92]. Upon treatment with vitamin $\mathrm{D}_{3}$, IGFBP3 mRNA is highly upregulated in LNCaP cells. In malignant and metastatic MCF10CA breast cancer cells, IGFBP3 transcripts were upregulated after treatment with a vitamin D analogue, Gemini [93]. IGFBP5 gene expression was induced after treatment with vitamin $\mathrm{D}_{3}$ in MCF-7 breast cancer cell lines [94].

An interaction in cellular signaling that is required for vitamin D's growth-inhibitory role in prostate cancer cells occurs between vitamin D and androgens [79]. Without androgen receptors, vitamin $\mathrm{D}$ is ineffective in its protective action, indicating that the protective function of the hormone requires signaling cross talk between both molecules.

Similarly, in the colon cancer cell line, Caco-2, vitamin D signaling is thought to modulate the apoptotic effects of transforming growth factor $\beta 1$ (TGF- $\beta 1$ ). Unlike its effect on normal epithelial cells, TGF $\beta$ cannot inhibit cell growth in Caco-2 (and other colon cancer-derived cell lines, such as SW-480). However, this resistance is reverted upon treatment of Caco-2 cell lines with vitamin D [95]. The effect of vitamin $\mathrm{D}_{3}$ appears to be via upregulation of IGF-II receptors and increased expression of TFG- $\beta 1$ itself in these cell lines. Furthermore, the apparent sensitization of cells to apoptosis by vitamin $\mathrm{D}$ in otherwise apoptosis-resistant malignant cell lines indicates an important role for vitamin $\mathrm{D}$ in the treatment of resistant refractory tumors. Vitamin D interacts with TGF- $\beta-$ SMAD1 signaling, blocks transcriptional expression of cell cycle proteins and inhibits the action of cell cycle protein cyclins $\mathrm{D}_{1}, \mathrm{D}_{2}, \mathrm{D}_{3}$ and $\mathrm{E}$. Vitamin $\mathrm{D}$ can also inhibit epidermal growth factor signaling and its mitogenic Ras signaling [40,96,97].

Wnt signaling activation is a key culprit in the pathogenesis of several cancers [98-101]. Wnt acts through the nuclear localization of $\beta$-catenin and its association with downstream transcription factors, such as TCF1 (also known as TCF7) and TCF4 (also known as TCF7L2). Upon nuclear localization, $\beta$-catenin can activate several genes involved in tumor growth, metastasis or angiogenesis. Wnt can 
upregulate cell cycle progression genes, such as cyclin D, c-Myc and c-jun, matrix metalloproteinase MMP-7 [102], and limb, bud and heart (LBH) transcription factor, which promote cell malignancy and metastasis. Wnt also upregulates endothelin 1, VEGF and interleukin 8 (IL-8), all of which promote angiogenesis, required to feed aggressive tumors [103-105]. Wnt also downregulates E-cadherin, required for cellular adhesion [106]. This downregulation may modulate the metastatic transformation associated with Wnt-activated tumor cells [107]. The antitumor effects of vitamin D that antagonize Wnt signaling action have been best demonstrated in breast, colorectal and prostate cancer cells. Vitamin D treatment downregulates several of the above tumorigenesis-promoting genes. This action is modulated by the genomic effects of VDR interaction with $\beta$-catenin and, therefore, suppression of Wnt-activated transcription induction of the above-mentioned genes [85,94,107-112]. Vitamin D also upregulates the Wnt antagonist, DKK-1, thus suppressing Wnt activation and associated transformation [112,113].

Vitamin D treatment blocks production of IL-1 $\beta$ in macrophages [114] and, hence, blocks inflammation associated with colon carcinoma progression. This inactivation of IL-1 $\beta$ suppresses inflammation and, in turn, Wnt signaling activation in colon cancer epithelial cells required for the progression of colon tumors [115]. The suppressive effects of vitamin D on inflammation have also been confirmed through studies that have shown that vitamin D can suppress IL-1 $\beta$, IL-6 and IL-17 and NF- $\mathrm{KB}$ in inflammation associated with breast and prostate cancer cells [107,116,117].

\subsection{Autophagy}

Vitamin D regulates cancer-associated autophagy. Autophagy is important in the prevention of tumor progression in vivo [118,119]. Autophagy allows cells to survive in conditions of stress, such as low oxygen or nutrient deprivation, through digestion of cellular debris or accumulated damaged organelles. Such debris may damage the cell and, hence, affect viability and survival. Although it may be considered a contradiction to accept that promoting cell survival in tumor cells would be warranted, studies in HL60 myeloid leukemia cells and in MCF-7 breast cancer cell lines indicate that activating autophagy pathways by the hormone, vitamin $\mathrm{D}$, is important in exciting signaling pathways mediating the tumor-suppressive role of vitamin D. Vitamin D treatment of tumor cells seems to mediate upregulation of a protein known as beclin-1, which interacts with PI3 kinase (PI3K), which, in turn, inhibits mTOR, responsible for promoting tumor growth and progression. The specific inhibition of mTOR signaling is one that suppresses molecules, such as CDK inhibitors, p19 and p27, but is independent of p53-mediated mechanisms. Vitamin D treatment is crucial for maintaining cell viability and survival via signaling pathways that require PI3K and mitogen-activated protein kinase signaling and that are independent of pathways eliciting apoptosis. Such signaling activation is effective at early stages of cellular damage, which is associated with carcinogenesis (and cancer therapy), and where neovascularization of tissues is absent. Treatment with vitamin D in such tumors at early stages of cellular transformation would induce autophagy with the aim of clearing damaged chromosomes and organelle debris [120]. After autophagy, p53 and other tumor-suppressor genes can either initiate cellular repair cascades if tumorigenesis is in its earlier stages or induce apoptosis in cells sensitized for treatment with radiotherapy or chemotherapy [119,121] Moreover, the beneficial effects of vitamin D-induced autophagy have been postulated to be exerted via attenuation of inflammation 
associated with tumorigenesis. However, because autophagy effects can promote both cell survival and inhibition of tumor progression, albeit under different cellular environments, the balance between both these opposing mechanisms on vitamin D treatment needs further study. Such studies will help determine the exact sequence and dose of vitamin $\mathrm{D}$ treatment relevant as an adjuvant anticancer drug therapy in combination with tumor treatments [36,122-124].

\subsection{Lessons from Animal Models}

Animal models offer additional supportive evidence that demonstrates the effective role of vitamin D in preventing uncontrollable hyperplasia and neoplasia leading to tumor formation [24]. Several kinds of animal models support this notion:

- VDR-knockout mouse models of VDR (VDRKO or $\mathrm{VDR}^{-/}$) vs. wild-type counterparts (VDRWT)

- Animals supplemented with vitamin D

- Animal models in which tumorigenesis is chemically induced before animals are supplemented with vitamin $\mathrm{D}$ or its analogues

- VDRKO models where tumors are implanted or transfected

- knockout animal or heterozygotes of other genes (e.g., APC ${ }^{\min /+}$ or nude mice) subsequently supplemented with vitamin D

Two initial VDRKO models have been established and subsequently reproduced by others to characterize the in vivo role of VDR in animal models [125,126]. In vivo, the effects of vitamin D on cellular proliferation and terminal differentiation differed between tissues; some tissue types showed hypoplasia and impaired development, whereas other tissues displayed clear hyperplasia. For example, the knockout mice, $\mathrm{VDR}^{-/-}$, exhibit growth retardation, impairment of bone formation, osteomalacia, alopecia, impaired folliculogenesis and uterine hypoplasia. Furthermore, transfection of mice with Lewis lung carcinoma cells shows that $\mathrm{VDR}^{-/-}$mice display significantly reduced metastasis of lung cancer cells compared with VDRWT animals [127].

In contrast, $\mathrm{VDR}^{-/-}$mice show hyperproliferation in mammary glands, the parathyroid gland and the descending colon. $\mathrm{VDR}^{-/}$mice displayed colonic cell division and increased expression of cell proliferation markers, PCNA (proliferating cell nuclear antigen) and cyclin D1. Scientists in the Cross lab later confirmed the $\mathrm{VDR}^{-/-}$model as a suitable model of colorectal hyperproliferation and DNA damage [128,129].

Using the $\mathrm{VDR}^{-/-}$mouse, Zinser and colleagues [130] demonstrated the role of vitamin $\mathrm{D}$ and its receptor in mammary gland morphogenesis. Comparing $\mathrm{VDR}^{--}$mice with VDRWT, they showed that mammary glands from developing VDR mice at puberty were heavier and exhibited faster growth and ductal branching than their VDRWT counterparts. In organ culture, mammary tissues from $\mathrm{VDR}^{-/-}$ treated with estrogen or progesterone exhibited greater hormonal sensitivity than VDRWT. After pregnancy and lactation, $\mathrm{VDR}^{-/-}$mice showed delayed breast gland involution after offspring weaning compared with VDRWT. Mehta and colleagues [131,132] demonstrated in rodent mammary organ culture that treatment with a noncalcemic vitamin D analogue significantly reduces tumor lesion incidence at both the early initiation and promotion stages. In dietary supplementation studies, 
Jacobson and colleagues [133] demonstrated in dimethylbenzanthracene (DMBA)-treated rats that rats fed on low vitamin D diets had higher tumor incidence than those fed vitamin D-replete diets. VanWeelden and colleagues transplanted nude mice (nu/nu mice) with MCF-7 breast cancer xenografts and, then, followed the treatment with supplementation. Mice were either supplemented with the low-calcemic vitamin D analogue (EB1089) or placebo pellets given to corresponding control subjects. This supplementation lasted for five weeks. In animals administered the vitamin D analogue, cell proliferation in tumors was reduced two-fold compared with control mice. Moreover, the rate of apoptosis was enhanced in EB1089-treated mice, which also experienced significant regression of implanted breast tumors compared with control subjects [134]. These studies indicate that vitamin $\mathrm{D}$ action via the VDR is essential to modulate mammary gland proliferation and induce differentiation [130,135,136]. Moreover, such studies indicate an in vivo cytoprotective role for vitamin D (and its analogues) in cancer prevention [134,137]. Xu and colleagues suggest through their studies on $\mathrm{APC}^{\mathrm{min} /+}$ heterozygous mouse models that the in vivo growth-modulating effect of vitamin $\mathrm{D}$ might be a result of a signaling interplay that allows vitamin $\mathrm{D}$ to block the mitogenic effects of growth factors implicated in neoplasty [138,139].

Moreover, deletion of the VDR gene in $\mathrm{VDR}^{-/}$mice predisposes these mice to higher risk and susceptibility to chemically-induced cancers of the skin, prostate, blood, lymph and breast. For example, treatment of VDRKO mice with DMBA dysregulates skin proliferation and hyperproliferates both basal and epidermal cells with reduced epidermal differentiation. DMBA induced higher incidence of cutaneous lesions in $\mathrm{VDR}^{-/}$mice than in VDRWT [140-142]. However, $\mathrm{VDR}^{-/}$mice do not spontaneously develop skin tumors without predisposition to carcinogens. Upon DMBA treatment, VDRKO mice also exhibit higher incidence of alveolar and ductal hyperplasias and 16\% higher lymphoblastic and thymic lymphomas than VDRWT counterparts. No observed tumor development occurred in tissues, such as ovary, uterus, lung and liver [130,142]. Similarly, in LPB-Tag transgenic mice, $\mathrm{pRB}$ and $\mathrm{p} 53$ tumor-suppressor genes are inactivated, causing prostate cancer, cellular proliferation and tumor progression much faster in VDRKO mice than in VDRWT. These differences are abolished upon treatment with testosterone. This finding indicated that vitamin D has a growth-modulating effect on cell growth through measured signaling interplay with other growth factors [143].

\subsection{Evidence for Vitamin D and Cancer}

The solar ultraviolet-B (UVB)-vitamin D-cancer hypothesis was proposed by the brothers Cedric and Frank Garland after seeing the atlas of colon cancer mortality rates (MRs) in the United States as beginning graduate students at Johns Hopkins University in 1974. They recognized a general inverse correlation between the regional doses of sunlight and colon cancer MRs. Their seminal paper was published in 1980 [144]. They later added breast [145] and ovarian [146] cancer to the list of cancers with reduced MRs in regions of higher solar radiation.

They used the ecological approach, which compares disease outcomes averaged by geographical units with risk-modifying factors, providing perhaps the strongest evidence that solar UVB and vitamin D reduce the risk of cancer. The evidence has been reviewed in recent papers [147,148]. The reasons the ecological approach is strong for cancer include: that many cases are included, that solar UVB, through production of vitamin D, is a significant risk reduction factor for many types of cancer, 
that other risk-modifying factors, such as ethnic background and smoking, can be used in the analyses and that cancers develop slowly.

Single-country ecological studies have provided strong and relatively consistent findings for many types of cancer. Single countries have the advantages for ecological studies that the populations are reasonably homogeneous, that they have similar diets and smoking habits, etc., but if not, the differences can be easily modeled, as has been done for the United States in an ecological study that used solar UVB doses for July, lung cancer MRs as the index of smoking and alcohol consumption, those of Hispanic heritage included in the category "white Americans", poverty level and urban/rural residence [149]. The findings for UVB were similar to those found in an earlier study that used only UVB doses, but omitted several states with high Hispanic population rates [150]. The results for alcohol consumption, Hispanic heritage and smoking were in good agreement with the journal literature.

There have been several solar UVB indices used in single-country ecological studies: annual solar radiation doses [144,151], solar UVB from the Total Ozone Monitoring System (TOMS) operated by NASA [149,150,152-154] and latitude [155-160]. A new set of solar UVB dose by month for North America is also available [161]. In some studies, indices of personal UVB irradiance were used: non-melanoma skin cancer in Spain [157] and California [159] and lip cancer less lung cancer in Nordic countries [162]. No factor other than vitamin D production has been proposed to explain the inverse correlations between the solar UVB indices and cancer incidence and/or MRs except for prostate cancer. It was noticed that the geographical variation of prostate cancer MR in the United States shared many features with the atlas of greatest ancestry by county for 2000 [163]. That finding inspired a multi-country ecological study involving genetics, diet and socioeconomic status. The hypothesized genetic link was to the apolipoprotein E epsilon4 (ApoE4) allele, an important risk factor for Alzheimer's disease [164]. Two important functions of this allele are to increase the production of insulin and cholesterol in order for those with this allele to be able to store more of the excess energy consumed in order to last between feasts. This allele is more common among hunter-gatherer people and those living at high northern latitudes. Several dietary supply factors were considered, and the energy derived from cereals/grains was found to be inversely correlated with prostate cancer incidence and MRs. The index of socioeconomic status used was gross national product per capita. Multiple linear regression analyses using these three factors found an adjusted $\mathrm{R}$ of about 0.5 , with all three factors having significant correlations with prostate cancer, ApoE4 and gross national product (GNP)/capita as risk factors [164]. Numerous studies have investigated the role of genes in the risk of prostate cancer. Only one other study identified ApoE4 as a risk factor, however [165]. Observational studies generally do not find that serum 25-hydroxyvitmain D $(25(\mathrm{OH}) \mathrm{D})$ levels are associated with the risk of prostate cancer [166].

Table 2 summarizes the findings from various single-country ecological studies. 
Table 2. Cancers for which inverse correlations between incidence and/or mortality rates (MRs) were found with respect to indices of solar UVB dose in single-country studies (references to be supplied).

\begin{tabular}{|c|c|c|c|c|c|c|c|c|}
\hline Cancer & $\begin{array}{c}\text { MR } \\
\text { (deaths } / 100,000 / \\
\text { Year) * } \\
\end{array}$ & $\begin{array}{c}\text { US } \\
{[149,152]}\end{array}$ & $\begin{array}{c}\text { Australia } \\
{[155]}\end{array}$ & $\begin{array}{c}\text { China } \\
{[153,156]}\end{array}$ & $\begin{array}{c}\text { France } \\
{[158]}\end{array}$ & $\begin{array}{r}\text { Japan } \\
{[151]}\end{array}$ & $\begin{array}{c}\text { Nordic } \\
\text { countries } \\
{[162]} \\
\end{array}$ & $\begin{array}{l}\text { Spain } \\
{[157]}\end{array}$ \\
\hline Lung & 69.4 & & & $\mathrm{X}$ & & & $\mathrm{X}$ & $\mathrm{X}$ \\
\hline Breast & 26.9 & $\mathrm{X}$ & $\mathrm{X}$ & $\mathrm{X}$ & $\mathrm{X}$ & & $\mathrm{X}$ & $\mathrm{X}$ \\
\hline Colorectal & 24.5 & $\mathrm{X}$ & $\mathrm{X}$ & $\mathrm{X}$ & $\mathrm{X}$ & $\mathrm{X}$ & $\mathrm{X}$ & $\mathrm{X}$ \\
\hline Prostate & 22.0 & $\mathrm{X}$ & $\mathrm{X}$ & & & & $\mathrm{X}$ & \\
\hline Colon & 20.1 & $\mathrm{X}$ & $\mathrm{X}$ & $\mathrm{X}$ & $\mathrm{X}$ & $\mathrm{X}$ & $\mathrm{X}$ & $\mathrm{X}$ \\
\hline Pancreatic & 10.2 & $\mathrm{X}$ & $\mathrm{X}$ & & & $\mathrm{X}$ & $\mathrm{X}$ & $\mathrm{X}$ \\
\hline Leukemia & 8.8 & $\mathrm{X}$ & $\mathrm{X}$ & $\mathrm{X}$ & & $\mathrm{X}$ & & \\
\hline Ovarian & 8.4 & $\mathrm{X}$ & $\mathrm{X}$ & & & & & $\mathrm{X}$ \\
\hline Gastric & 7.3 & $\mathrm{X}$ & $\mathrm{X}$ & $\mathrm{X}$ & & $\mathrm{X}$ & $\mathrm{X}$ & $\mathrm{X}$ \\
\hline $\begin{array}{l}\text { non-Hodgkin’s } \\
\text { lymphoma (NHL) }\end{array}$ & 7.0 & $\mathrm{X}$ & $\mathrm{X}$ & & & & & $\mathrm{X}$ \\
\hline Bladder & 6.6 & $\mathrm{X}$ & & $\mathrm{X}$ & & & $\mathrm{X}$ & $\mathrm{X}$ \\
\hline Brain & 5.2 & & & & & & & $\mathrm{X}$ \\
\hline Renal & 4.9 & $\mathrm{X}$ & & & & & $\mathrm{X}$ & \\
\hline Esophageal & 4.8 & $\mathrm{X}$ & $\mathrm{x}$ & $\mathrm{X}$ & $\mathrm{X}$ & $\mathrm{X}$ & $\mathrm{x}$ & $\mathrm{X}$ \\
\hline Rectal & 4.4 & $\mathrm{X}$ & & $\mathrm{X}$ & & $\mathrm{X}$ & $\mathrm{x}$ & $\mathrm{X}$ \\
\hline Oral, pharyngeal & 4.0 & $\mathrm{X}$ & & & & & $\mathrm{x}$ & \\
\hline Endometrial & 3.7 & $\mathrm{X}$ & & & $\mathrm{X}$ & & & $\mathrm{X}$ \\
\hline Cervical & 3.2 & & & $\mathrm{x}$ & $\mathrm{x}$ & & & \\
\hline Gallbladder & 1.1 & $\mathrm{X}$ & & & & $\mathrm{X}$ & $\mathrm{X}$ & $\mathrm{X}$ \\
\hline $\begin{array}{l}\text { Hodgkin's } \\
\text { lymphoma }\end{array}$ & 1.1 & $\mathrm{X}$ & & & & & & $\mathrm{X}$ \\
\hline Thyroid & 0.4 & $\mathrm{X}$ & & & & & & $\mathrm{X}$ \\
\hline Vulvar & 0.3 & $\mathrm{X}$ & & & & & & \\
\hline
\end{tabular}

* [167]; MR, MR for males, United States, 1970-94, unless for a female cancer.

The types of cancer are ordered by the MR for males (females for female cancers) for the United States for the period 1970-1994 [167]. The reason for doing so is that the more common a type of cancer is, the easier it is to include enough cases in the study to find significant correlations with solar UVB or vitamin D [168]. As expected, the types of cancer with the higher MRs generally have more findings of inverse correlation with solar UVB doses. For those with fewer significant findings relative to others with similar MRs, this suggests that the beneficial effect of UVB and vitamin D is weak or nonexistent, such as for brain cancer. For those with a relatively higher number of findings for its MR range, it is likely that the effects of UVB and vitamin D are strong, such as for esophageal and gallbladder cancer.

These findings are discussed in greater detail in Grant [147]. Several things can be inferred from the table. One is that the types of cancer with the higher MRs are generally more likely to have been found inversely correlated with the solar UVB indices. This is reasonable, since the uncertainty of each value is reduced [168]. There is little support for vitamin D reducing the risk of brain cancer, as it is a 
relatively common cancer, but with only one supporting study. On the other hand, the findings for thyroid and vulvar cancers are considered good evidence of the protection by vitamin $\mathrm{D}$, since the MRs are so low.

While ecological studies may provide the earliest and, in some respects, best evidence for a role of solar UVB and vitamin D in reducing the risk of cancer, such findings should be supported by other types of studies in order to evaluate the findings from ecological studies. The next most common type of epidemiological study used to evaluate the role of solar UVB and vitamin D in reducing the risk of cancer is the observational study. There are two types of observational studies: case-control studies in which serum the $25(\mathrm{OH}) \mathrm{D}$ level is determined near the time of cancer diagnosis; and nested case-control studies from cohort studies. The perceived advantages of the nested case-control studies include unbiased matching of controls and using 25(OH)D levels, UVB doses or irradiances not affected by the health outcome. Case-control studies could have serum 25(OH)D levels affected by the disease state. However, there does not appear to be any evidence that the existence of cancer per se affects serum 25(OH)D levels or behavior, since most people do not know they have cancer until it is diagnosed. The primary problem of the cohort study approach is that serum $25(\mathrm{OH}) \mathrm{D}$ levels from blood drawn at time of enrollment are generally used in the analysis, no matter how many years have elapsed since enrollment. As shown in a pair of papers that examined health outcome with respect to years after enrollment, linear declines were found in risk reduction with respect to follow-up time for cancers [169] and all-cause MR [170].

Table 3 presents an overview of the findings from observational studies supporting the UVB-vitamin D-cancer hypothesis.

Table 3. Results from observational studies of cancer incidence with respect to UVB irradiance or serum $25(\mathrm{OH}) \mathrm{D}$ levels.

\begin{tabular}{|c|c|c|c|c|}
\hline Cancer & [171] & [154] & [172] & Others \\
\hline Bladder & $\mathrm{X}^{*}$ & $\mathrm{X}$ & $\mathrm{X}$ & [173] \\
\hline Brain & & & & \\
\hline Breast & & & & Case-control \\
\hline Colon & & $\mathrm{X}$ & & Cohort \\
\hline Colorectal & $\mathrm{X}$ & & & Cohort \\
\hline Endometrial & & & & [174] \\
\hline Esophageal & $\mathrm{X}$ & & & \\
\hline $\begin{array}{c}\text { Esophageal, squamous } \\
\text { cell }\end{array}$ & & $X^{*}$ & & \\
\hline Gastric & $X^{*}$ & & $X^{*}$ & \\
\hline Head and neck & & & $\mathrm{X}$ & {$[175]$} \\
\hline Hepatoblastoma & & & & [160] \\
\hline Leukemia & $\mathrm{X}$ & & & \\
\hline $\begin{array}{l}\text { Leukemia, acute } \\
\text { lymphoblastic }\end{array}$ & & & & [160] \\
\hline Liver & & & $\mathrm{X}^{*}$ & \\
\hline Lung & $X^{*}$ & & $\mathrm{X}$ & \\
\hline $\begin{array}{l}\text { Lung, adeno, } \\
\text { squamous cell }\end{array}$ & & X & & \\
\hline
\end{tabular}


Table 3. Cont.

\begin{tabular}{|c|c|c|c|c|}
\hline NHL & $\mathrm{X}^{*}$ & $\bar{X}$ & & {$[160,176]$} \\
\hline Oral/pharyngeal & $\mathrm{X}$ & & & \\
\hline Ovarian & & & & [177] \\
\hline Pancreatic & $\mathrm{X}$ & $\mathrm{X}$ & $\mathrm{X}^{*}$ & [178] \\
\hline Pleura & & $\mathrm{X}$ & & \\
\hline Prostate & $\mathrm{X}^{*}$ & $\mathrm{X}$ & & \\
\hline Rectal & & $\mathrm{X}^{*}$ & & Cohort \\
\hline Renal & $X^{*}$ & $\mathrm{X}$ & $\mathrm{X}$ & [179] \\
\hline Thyroid & & $\mathrm{X}$ & & {$[180]$} \\
\hline
\end{tabular}

It is noted that the study from the Health Professionals Follow-up Study [171] and the National Institutes of Health-American Association of Retired Persons (NIH-AARP) Diet and Health study [154] were based, in large part, on solar UVB doses. That was explicit in Lin [154] and implicit in Giovannucci [171] in that it used a modeled serum 25(OH)D level based on measurements of serum $25(\mathrm{OH}) \mathrm{D}$ levels in 1000 men with respect to such factors as geographical location, skin pigmentation and leisure time spent out of doors. Other studies based on UVB were those for endometrial cancer [181], hepatoblastoma, acute lymphoblastic leukemia and NHL [160,176].

For colorectal cancer, cohort studies with follow-up times out to 12 years found a significantly reduced risk for higher serum $25(\mathrm{OH}) \mathrm{D}$ levels [158]. However, for breast cancer, significantly reduced risk for higher serum $25(\mathrm{OH}) \mathrm{D}$ levels was reported only for follow-up times less than three years [169]. The reason for the different findings is that breast cancer is a rapidly developing cancer, while colorectal cancer is not. For example, breast cancer is diagnosed more frequently in spring and fall [182]. The authors suggested that vitamin D reduces breast cancer risk in summer, while melatonin does in winter, due to low sunlight levels.

\subsection{Clinical Trials}

There have been two randomized controlled trials (RCT) using vitamin D and calcium that found a beneficial effect in reducing cancer incidence. The first one was one conducted on post-menopausal women in Nebraska [183]. Those in the treatment arms took $1450 \mathrm{mg} / \mathrm{day}$ calcium or $1450 \mathrm{mg} / \mathrm{day}$ calcium plus $1100 \mathrm{IU} /$ day vitamin $\mathrm{D}_{3}$. At the time of enrollment, the mean serum 25(OH)D level was $72 \mathrm{nmol} / \mathrm{L}$. At the end of the first year, those taking vitamin $\mathrm{D}$ plus calcium had a mean serum $25(\mathrm{OH}) \mathrm{D}$ level of $96 \mathrm{nmol} / \mathrm{L}$, while those in the other two arms had $71 \mathrm{nmol} / \mathrm{L}$. Between the ends of the first and fourth years, those taking only calcium had a $44 \%$ reduction in all-cancer incidence, while those taking calcium plus vitamin D had a $77 \%$ reduction. Based on the relationship between breast cancer incidence rates from case-control studies vs. serum $25(\mathrm{OH}) \mathrm{D}$ level, the expected reduction would be $18 \%$. The difference between $44 \%$ and $77 \%$ is $33 \%$. Given the uncertainty in both values, and the confounding of vitamin D with calcium, the finding in the RCT is in reasonable agreement with the cancer risk-25(OH)D relation. Calcium has been found to reduce the risk of cancer in a number of studies [184]. 
The second successful vitamin D/calcium RCT was from a reanalysis of a subset of data from the Women's Health Initiative study. Participants were given $400 \mathrm{IU} /$ day vitamin $\mathrm{D}_{3}$ and $1500 \mathrm{mg} /$ day calcium, but many did not comply and take all of the supplements. For those participants who had not been taking vitamin D or calcium supplements prior to enrolling, there were significant decreases of total, breast and invasive breast cancer of $14 \%-20 \%$ and, nonsignificantly, a reduced risk of colorectal cancer of $17 \%$ [185]. For those taking vitamin D and/or calcium prior to enrollment, there was no beneficial effect of taking them during the study. This reduction is about twice that expected from vitamin $\mathrm{D}$ alone, so it probably includes a contribution from calcium.

There are a number of reasons why there are so few vitamin D RCTs reporting a reduced risk of cancer. One is that for many years, researchers used $400 \mathrm{IU} /$ day vitamin $\mathrm{D}_{3}$. This amount reduces the risk of rickets, but not much else. It is only in the past decade that many of the non-calcemic benefits of vitamin D were reported. For non-calcemic benefits, higher serum $25(\mathrm{OH}) \mathrm{D}$ levels are required. A second reason is that most of the vitamin D RCTs treated vitamin D as a drug, assuming that other sources of vitamin $\mathrm{D}$ were unimportant and that there was a simple dose-response relation between oral vitamin D and the serum 25(OH)D level. In fact, the vitamin D-serum 25(OH)D level relation is nonlinear and eventually saturates [186]. Proper vitamin D RCTs should have a model relationship between serum 25(OH)D level and health outcome, generally from observational studies, enroll people at the lower end of this relationship, supplement them with sufficient vitamin $\mathrm{D}_{3}$ to raise their serum $25(\mathrm{OH}) \mathrm{D}$ level to the upper end and measure serum $25(\mathrm{OH}) \mathrm{D}$ levels at the time of enrollment and after a year of supplementing, as well as consider other sources of vitamin D, such as solar UVB irradiance. The guidelines for conducting vitamin D RCTs were outlined in a recent paper [187].

\subsection{Cancer Survival}

Another way to examine whether vitamin D reduces the risk of cancer is to investigate whether those with higher serum $25(\mathrm{OH}) \mathrm{D}$ levels at the time of cancer diagnosis have better survival rates than those with lower levels. Those diagnosed with colorectal cancer with serum 25(OH)D levels in the upper quartile had half the MR of those in the lower quartile [188]. Such findings led to a study on the disparities in cancer survival rates for black Americans compared to white Americans [189]. It was found that there are disparities for 13 types of cancer after consideration of socioeconomic status, stage at diagnosis and treatment: bladder, breast, colon, endometrial, lung, ovarian, pancreatic, prostate, rectal, testicular and vaginal cancer, Hodgkin lymphoma and melanoma. Solar UVB doses and/or serum 25(OH)D levels have been reported to be inversely correlated with incidence and/or MRs for all of these cancers. The disparities not accounted for by socioeconomic status, stage at diagnosis and treatment ranged from $0 \%$ to $50 \%$, with a mean value near $25 \%$. This value is consistent with the disparities in serum 25(OH)D levels for black and white Americans: $40 \mathrm{nmol} / \mathrm{L}$ for black Americans and $65 \mathrm{nmol} / \mathrm{L}$ for white Americans [190].

\subsection{Hill's Criteria for Causality}

A. Bradford Hill laid down the criteria for causality in a biological system in 1965 [191]. The primary criteria appropriate for UVB irradiance and vitamin D include strength of association, consistent findings in different populations, temporality, biological gradient, plausibility (e.g., 
mechanisms), experiment (e.g., RCT) and analogy. As seen from the information presented in this work, most of the criteria are satisfied to a reasonable extent, especially for breast and colorectal cancer. By invoking analogy, many of the other cancers also qualify based on the findings in ecological studies. Hill's criteria for causality have been applied to many types of cancer, finding them largely satisfied for breast and colorectal cancer and somewhat satisfied for several other types of cancer [192], as well as for breast cancer [193].

\section{Recommendations/Conclusions}

Based on the evidence reviewed in this paper, there is very good-to-excellent scientific evidence that solar UVB irradiance and vitamin D reduce the risk of many types of cancer. However, acceptance by public policy review boards has not yet accepted the evidence. Part of the reason is that they generally require well-conducted randomized controlled trials rather than ecological or observational studies before making recommendations. Another reason is that UV irradiance is considered the most important risk factor for melanoma and non-melanoma skin cancer, so many public health bodies are reluctant to recommend more sun exposure.

\section{Conflicts of Interest}

WBG receives funding from Bio-Tech Pharmacal (Fayetteville, AR) and the Sunlight Research Forum (Veldhoven) and has received funding from the UV Foundation (McLean, VA), the Vitamin D Council (San Luis Obispo, CA), and the Vitamin D Society (Canada).

\section{References}

1. Severo, M.; Lopes, C.; Lucas, R.; Barros, H. Development of a tool for the assessment of calcium and vitamin D intakes in clinical settings. Osteoporos. Int. 2009, 20, 231-237.

2. Calvo, M.S.; Babu, U.S.; Garthoff, L.H.; Woods, T.O.; Dreher, M.; Hill, G.; Nagaraja, S. Vitamin D2 from light-exposed edible mushrooms is safe, bioavailable and effectively supports bone growth in rats. Osteoporos. Int. 2013, 24, 197-207.

3. Hohman, E.E.; Martin, B.R.; Lachcik, P.J.; Gordon, D.T.; Fleet, J.C.; Weaver, C.M. Bioavailability and efficacy of vitamin D2 from UV-irradiated yeast in growing, vitamin D-deficient rats. J. Agric. Food Chem. 2011, 59, 2341-2346.

4. Heaney, R.P.; Armas, L.A.; French, C. All-Source basal vitamin D inputs are greater than previously thought and cutaneous inputs are smaller. J. Nutr. 2013, 143, 571-575.

5. Mellanby, E. An experimental investigation on rickets. Lancet 1919, 1, 407-412.

6. McCollum, E.V.; Simmonds, N.; Becker, J.E.; Shipley, P.G. An experimental demonstration of the existence of a vitamin which promotes calcium deposition. J. Biol. Chem. 1922, 53, 293-298.

7. Hess, A.F.; Unger, L.F. Cure of infantile rickets by sunlight. J. Am. Med. Assoc. 1921, 77, 39.

8. Steenbock, H.; Black, A. A fat-soluble vitamins. XVII. The induction of growth-promoting and clcifying properties in a ration by exposure to ultraviolet light. J. Biol. Chem. 1924, 61, 405-422.

9. Askew, F.A.; Bourdillon, B.R.; Bruce, H.M.; Jenkins, R.G.C. The distillation of vitamin D. Proc. R. Soc. 1931, B107, 76-90. 
10. Windaus, A.; Schenck, F.; von Werder, F. Uber das antirachitisch wirksame bestrahlungsproduct aus 7-dehydro-cholesterin. Hoppe-Seylers Z. Physiol. Chem. 1936, 241, 100-103 (in German).

11. McCollum, E.V. The paths to the discovery of vitamins A and D. J. Nutr. 1967, 91, 11-16.

12. Wolf, G. The discovery of vitamin D: The contribution of adolf windaus. J. Nutr. 2004, 134, 1299-1302.

13. Holick, M.F.; McNeill, S.C.; MacLaughlin, J.A.; Holick, S.A.; Clark, M.B.; Potts, J.T., Jr. Physiologic implications of the formation of previtamin D3 in skin. Trans. Assoc. Am. Phys. 1979, 92, 54-63.

14. Holick, M.F.; Richtand, N.M.; McNeill, S.C.; Holick, S.A.; Frommer, J.E.; Henley, J.W.; Potts, J.T., Jr. Isolation and identification of previtamin D3 from the skin of rats exposed to ultraviolet irradiation. Biochemistry 1979, 18, 1003-1008.

15. Holick, S.A.; Holick, M.F.; MacLaughlin, J.A. Chemical synthesis of [1 beta-3H] 1 alpha, 25-dihydroxyvitamin D3 and [1 alpha-3H] 1 beta, 25-dihydroxyvitamin D2: Biological activity of 1 beta, 25-dihydroxyvitamin D3. Biochem. Biophys. Res. Commun. 1980, 97, 1031-1037.

16. Holick, M.F.; MacLaughlin, J.A.; Clark, M.B.; Holick, S.A.; Potts, J.T., Jr.; Anderson, R.R.; Blank, I.H.; Parrish, J.A.; Elias, P. Photosynthesis of previtamin D3 in human skin and the physiologic consequences. Science 1980, 210, 203-205.

17. Zusman, I.; Hirsh, B.E.; Edelstein, S.; Ornoy, A. Transplacental effects of 1,25dihydroxycholecalciferol and of 24,25-dihydroxycholecalciferol on the limb skeleton of fetuses and offspring rats. Acta Anat. (Basel) 1981, 111, 343-351.

18. Guo, Y.D.; Strugnell, S.; Back, D.W.; Jones, G. Transfected human liver cytochrome p-450 hydroxylates vitamin D analogs at different side-chain positions. Proc. Natl. Acad. Sci. USA 1993, 90, 8668-8672.

19. Cheng, J.B.; Levine, M.A.; Bell, N.H.; Mangelsdorf, D.J.; Russell, D.W. Genetic evidence that the human cyp2r1 enzyme is a key vitamin D 25-hydroxylase. Proc. Natl. Acad. Sci. USA 2004, 101, 7711-7715.

20. Takeyama, K.; Kitanaka, S.; Sato, T.; Kobori, M.; Yanagisawa, J.; Kato, S. 25-Hydroxyvitamin D3 1alpha-hydroxylase and vitamin D synthesis. Science 1997, 277, 1827-1830.

21. Dilworth, F.J.; Scott, I.; Green, A.; Strugnell, S.; Guo, Y.D.; Roberts, E.A.; Kremer, R.; Calverley, M.J.; Makin, H.L.; Jones, G. Different mechanisms of hydroxylation site selection by liver and kidney cytochrome p450 species (cyp27 and cyp24) involved in vitamin D metabolism. J. Biol. Chem. 1995, 270, 16766-16774.

22. Zehnder, D.; Bland, R.; Williams, M.C.; McNinch, R.W.; Howie, A.J.; Stewart, P.M.; Hewison, M. Extrarenal expression of 25-hydroxyvitamin D(3)-1 alpha-hydroxylase. J. Clin. Endocrinol. Metab. 2001, 86, 888-894.

23. Baker, A.R.; McDonnell, D.P.; Hughes, M.; Crisp, T.M.; Mangelsdorf, D.J.; Haussler, M.R.; Pike, J.W.; Shine, J.; O’Malley, B.W. Cloning and expression of full-length cdna encoding human vitamin D receptor. Proc. Natl. Acad. Sci. USA 1988, 85, 3294-3298.

24. Bouillon, R.; Carmeliet, G.; Verlinden, L.; van Etten, E.; Verstuyf, A.; Luderer, H.F.; Lieben, L.; Mathieu, C.; Demay, M. Vitamin d and human health: Lessons from vitamin D receptor null mice. Endocr. Rev. 2008, 29, 726-776. 
25. Bikle, D.D. Protective actions of vitamin D in UVB induced skin cancer. Photochem. Photobiol. Sci. 2012, 11, 1808-1816.

26. Rosen, C.J.; Adams, J.S.; Bikle, D.D.; Black, D.M.; Demay, M.B.; Manson, J.E.; Murad, M.H.; Kovacs, C.S. The nonskeletal effects of vitamin D: An endocrine society scientific statement. Endocr. Rev. 2012, 33, 456-492.

27. Mohr, S.B. A brief history of vitamin D and cancer prevention. Ann. Epidemiol. 2009, 19, 79-83.

28. Haussler, M.R.; Norman, A.W. Chromosomal receptor for a vitamin D metabolite. Proc. Natl. Acad. Sci. USA 1969, 62, 155-162.

29. McDonnell, D.P.; Mangelsdorf, D.J.; Pike, J.W.; Haussler, M.R.; O’Malley, B.W. Molecular cloning of complementary DNA encoding the avian receptor for vitamin D. Science 1987, 235, 1214-1217.

30. Rochel, N.; Wurtz, J.M.; Mitschler, A.; Klaholz, B.; Moras, D. The crystal structure of the nuclear receptor for vitamin D bound to its natural ligand. Mol. Cell 2000, 5, 173-179.

31. Lee, S.; Clark, S.A.; Gill, R.K.; Christakos, S. 1,25-Dihydroxyvitamin D3 and pancreatic beta-cell function: Vitamin D receptors, gene expression, and insulin secretion. Endocrinology 1994, 134, 1602-1610.

32. McGrath, J.J.; Feron, F.P.; Burne, T.H.; Mackay-Sim, A.; Eyles, D.W. Vitamin D3-implications for brain development. J. Steroid Biochem. Mol. Biol. 2004, 89-90, 557-560.

33. De Paula, F.J.; Dick-de-Paula, I.; Bornstein, S.; Rostama, B.; Le, P.; Lotinun, S.; Baron, R.; Rosen, C.J. VDR haploinsufficiency impacts body composition and skeletal acquisition in a gender-specific manner. Calcif. Tissue Int. 2011, 89, 179-191.

34. DeLuca, H.F. Overview of general physiologic features and functions of vitamin D. Am. J. Clin. Nutr. 2004, 80, 1689S-1696S.

35. Zanatta, L.; Zamoner, A.; Zanatta, A.P.; Bouraima-Lelong, H.; Delalande, C.; Bois, C.; Carreau, S.; Silva, F.R. Nongenomic and genomic effects of 1alpha,25(OH)2 vitamin D3 in rat testis. Life Sci. 2011, 89, 515-523.

36. Wang, Y.; Zhu, J.; DeLuca, H.F. Where is the vitamin D receptor? Arch. Biochem. Biophys. 2012, 523, 123-133.

37. Haussler, M.R.; Whitfield, G.K.; Haussler, C.A.; Hsieh, J.C.; Thompson, P.D.; Selznick, S.H.; Dominguez, C.E.; Jurutka, P.W. The nuclear vitamin D receptor: Biological and molecular regulatory properties revealed. J. Bone Miner. Res. 1998, 13, 325-349.

38. Rachez, C.; Suldan, Z.; Ward, J.; Chang, C.P.; Burakov, D.; Erdjument-Bromage, H.; Tempst, P.; Freedman, L.P. A novel protein complex that interacts with the vitamin D3 receptor in a ligand-dependent manner and enhances VDR transactivation in a cell-free system. Genes Dev. 1998, 12, 1787-1800.

39. Christakos, S.; Dhawan, P.; Liu, Y.; Peng, X.; Porta, A. New insights into the mechanisms of vitamin D action. J. Cell. Biochem. 2003, 88, 695-705.

40. Deeb, K.K.; Trump, D.L.; Johnson, C.S. Vitamin D signalling pathways in cancer: Potential for anticancer therapeutics. Nat. Rev. Cancer 2007, 7, 684-700.

41. Teichert, A.; Arnold, L.A.; Otieno, S.; Oda, Y.; Augustinaite, I.; Geistlinger, T.R.; Kriwacki, R.W.; Guy, R.K.; Bikle, D.D. Quantification of the vitamin D receptor-coregulator interaction. Biochemistry 2009, 48, 1454-1461. 
42. Gill, R.K.; Christakos, S. Identification of sequence elements in mouse calbindin-d28k gene that confer 1,25-dihydroxyvitamin D3- and butyrate-inducible responses. Proc. Natl. Acad. Sci. USA 1993, 90, 2984-2988.

43. Xie, Z.; Bikle, D.D. Cloning of the human phospholipase C-gammal promoter and identification of a DR6-type vitamin D-responsive element. J. Biol. Chem. 1997, 272, 6573-6577.

44. Kurokawa, R.; Yu, V.C.; Naar, A.; Kyakumoto, S.; Han, Z.; Silverman, S.; Rosenfeld, M.G.; Glass, C.K. Differential orientations of the DNA-binding domain and carboxy-terminal dimerization interface regulate binding site selection by nuclear receptor heterodimers. Genes Dev. 1993, 7 , $1423-1435$.

45. Crofts, L.A.; Hancock, M.S.; Morrison, N.A.; Eisman, J.A. Multiple promoters direct the tissue-specific expression of novel $n$-terminal variant human vitamin D receptor gene transcripts. Proc. Natl. Acad. Sci. USA 1998, 95, 10529-10534.

46. Sunn, K.L.; Cock, T.A.; Crofts, L.A.; Eisman, J.A.; Gardiner, E.M. Novel $n$-terminal variant of human VDR. Mol. Endocrinol. 2001, 15, 1599-1609.

47. Hsieh, J.C.; Shimizu, Y.; Minoshima, S.; Shimizu, N.; Haussler, C.A.; Jurutka, P.W.; Haussler, M.R. Novel nuclear localization signal between the two DNA-binding zinc fingers in the human vitamin D receptor. J. Cell. Biochem. 1998, 70, 94-109.

48. Michigami, T.; Suga, A.; Yamazaki, M.; Shimizu, C.; Cai, G.; Okada, S.; Ozono, K. Identification of amino acid sequence in the hinge region of human vitamin $\mathrm{D}$ receptor that transfers a cytosolic protein to the nucleus. J. Biol. Chem. 1999, 274, 33531-33538.

49. Kato, S.; Fujiki, R.; Kitagawa, H. Vitamin D receptor (VDR) promoter targeting through a novel chromatin remodeling complex. J. Steroid Biochem. Mol. Biol. 2004, 89-90, 173-178.

50. Fujiki, R.; Kim, M.S.; Sasaki, Y.; Yoshimura, K.; Kitagawa, H.; Kato, S. Ligand-Induced transrepression by VDR through association of WSTF with acetylated histones. EMBO J. 2005, 24, 3881-3894.

51. Kato, S.; Fujiki, R.; Kim, M.S.; Kitagawa, H. Ligand-Induced transrepressive function of VDR requires a chromatin remodeling complex, WINAC. J. Steroid Biochem. Mol. Biol. 2007, 103, 372-380.

52. Oda, Y.; Sihlbom, C.; Chalkley, R.J.; Huang, L.; Rachez, C.; Chang, C.P.; Burlingame, A.L.; Freedman, L.P.; Bikle, D.D. Two distinct coactivators, DRIP/mediator and SRC/p160, are differentially involved in VDR transactivation during keratinocyte differentiation. J. Steroid Biochem. Mol. Biol. 2004, 89-90, 273-276.

53. Oda, Y.; Chalkley, R.J.; Burlingame, A.L.; Bikle, D.D. The transcriptional coactivator drip/mediator complex is involved in vitamin $\mathrm{D}$ receptor function and regulates keratinocyte proliferation and differentiation. J. Investig. Dermatol. 2010, 130, 2377-2388.

54. Garcia-Bassets, I.; Kwon, Y.S.; Telese, F.; Prefontaine, G.G.; Hutt, K.R.; Cheng, C.S.; Ju, B.G.; Ohgi, K.A.; Wang, J.; Escoubet-Lozach, L.; et al. Histone methylation-dependent mechanisms impose ligand dependency for gene activation by nuclear receptors. Cell 2007, 128, 505-518.

55. Li, B.; Carey, M.; Workman, J.L. The role of chromatin during transcription. Cell 2007, 128, 707-719. 
56. Rachez, C.; Lemon, B.D.; Suldan, Z.; Bromleigh, V.; Gamble, M.; Naar, A.M.; Erdjument-Bromage, H.; Tempst, P.; Freedman, L.P. Ligand-dependent transcription activation by nuclear receptors requires the DRIP complex. Nature 1999, 398, 824-828.

57. Rachez, C.; Gamble, M.; Chang, C.P.; Atkins, G.B.; Lazar, M.A.; Freedman, L.P. The DRIP complex and SRC-1/p160 coactivators share similar nuclear receptor binding determinants but constitute functionally distinct complexes. Mol. Cell Biol. 2000, 20, 2718-2726.

58. Segal, J. Action of the thyroid hormone at the level of the plasma membrane. Endocr. Res. 1989, 15, 619-649.

59. Morley, P.; Whitfield, J.F.; Vanderhyden, B.C.; Tsang, B.K.; Schwartz, J.L. A new, nongenomic estrogen action: The rapid release of intracellular calcium. Endocrinology 1992, 131, 1305-1312.

60. Nemere, I.; Safford, S.E.; Rohe, B.; DeSouza, M.M.; Farach-Carson, M.C. Identification and characterization of 1,25D3-membrane-associated rapid response, steroid (1,25d3-MARRS) binding protein. J. Steroid Biochem. Mol. Biol. 2004, 89-90, 281-285.

61. Caffrey, J.M.; Farach-Carson, M.C. Vitamin D3 metabolites modulate dihydropyridine-sensitive calcium currents in clonal rat osteosarcoma cells. J. Biol. Chem. 1989, 264, 20265-20274.

62. Baran, D.T.; Sorensen, A.M.; Honeyman, T.W.; Ray, R.; Holick, M.F. 1 alpha,25-dihydroxyvitamin D3-induced increments in hepatocyte cytosolic calcium and lysophosphatidylinositol: Inhibition by pertussis toxin and 1 beta,25-dihydroxyvitamin D3. J. Bone Miner. Res. 1990, 5, 517-524.

63. Wali, R.K.; Baum, C.L.; Sitrin, M.D.; Brasitus, T.A. 1,25(OH)2 vitamin D3 stimulates membrane phosphoinositide turnover, activates protein kinase $\mathrm{C}$, and increases cytosolic calcium in rat colonic epithelium. J. Clin. Investig. 1990, 85, 1296-1303.

64. Morelli, S.; de Boland, A.R.; Boland, R.L. Generation of inositol phosphates, diacylglycerol and calcium fluxes in myoblasts treated with 1,25-dihydroxyvitamin D3. Biochem. J. 1993, 289, 675-679.

65. Baran, D.T.; Sorensen, A.M. Rapid actions of 1 alpha-25-dihydroxyvitamin D3 physiologic role. Proc. Soc. Exp. Biol. Med. 1994, 207, 175-179.

66. Sitrin, M.D.; Bissonnette, M.; Bolt, M.J.; Wali, R.; Khare, S.; Scaglione-Sewell, B.; Skarosi, S.; Brasitus, T.A. Rapid effects of 1,25(OH)2 vitamin D3 on signal transduction systems in colonic cells. Steroids 1999, 64, 137-142.

67. Norman, A.W.; Ishizuka, S.; Okamura, W.H. Ligands for the vitamin D endocrine system: Different shapes function as agonists and antagonists for genomic and rapid response receptors or as a ligand for the plasma vitamin D binding protein. J. Steroid Biochem. Mol. Biol. 2001, 76, 49-59.

68. Nemere, I.; Garbi, N.; Hammerling, G.; Hintze, K.J. Role of the 1,25D3-MARRS receptor in the 1,25(OH)2D3-stimulated uptake of calcium and phosphate in intestinal cells. Steroids 2012, 77 , 897-902.

69. Shi, H.; Norman, A.W.; Okamura, W.H.; Sen, A.; Zemel, M.B. 1alpha,25-Dihydroxyvitamin D3 modulates human adipocyte metabolism via nongenomic action. FASEB J. 2001, 15, 2751-2753.

70. Richard, C.L.; Farach-Carson, M.C.; Rohe, B.; Nemere, I.; Meckling, K.A. Involvement of 1,25D3-MARRS (membrane associated, rapid response steroid-binding), a novel vitamin D receptor, in growth inhibition of breast cancer cells. Exp. Cell Res. 2010, 316, 695-703. 
71. Jensen, S.S.; Madsen, M.W.; Lukas, J.; Binderup, L.; Bartek, J. Inhibitory effects of 1alpha,25-dihydroxyvitamin D(3) on the G(1)-S phase-controlling machinery. Mol. Endocrinol. 2001, 15, 1370-1380.

72. Salehi-Tabar, R.; Nguyen-Yamamoto, L.; Tavera-Mendoza, L.E.; Quail, T.; Dimitrov, V.; An, B.S.; Glass, L.; Goltzman, D.; White, J.H. Vitamin D receptor as a master regulator of the c-MYC/MXD1 network. Proc. Natl. Acad. Sci. USA 2012, 109, 18827-18832.

73. Meyer, M.B.; Goetsch, P.D.; Pike, J.W. VDR/RXR and TCF4/ $\beta$-catenin cistromes in colonic cells of colorectal tumor origin: Impact on c-FOS and c-MYC gene expression. Mol. Endocrinol. 2012, 26, 37-51.

74. Washington, M.N.; Kim, J.S.; Weigel, N.L. 1 $\alpha, 25$-dihydroxyvitamin D3 inhibits C4-2 prostate cancer cell growth via a retinoblastoma protein $(\mathrm{Rb})$-independent $\mathrm{G} 1$ arrest. Prostat 2011, 71, 98-110.

75. Li, P.; Li, C.; Zhao, X.; Zhang, X.; Nicosia, S.V.; Bai, W. p27(Kip1) stabilization and G(1) arrest by 1,25-dihydroxyvitamin $\mathrm{D}(3)$ in ovarian cancer cells mediated through down-regulation of cyclin E/cyclin-dependent kinase 2 and Skp1-Cullin-F-box protein/Skp2 ubiquitin ligase. J. Biol. Chem. 2004, 279, 25260-25267.

76. Akutsu, N.; Lin, R.; Bastien, Y.; Bestawros, A.; Enepekides, D.J.; Black, M.J.; White, J.H. Regulation of gene expression by 1alpha,25-dihydroxyvitamin D3 and its analog EB1089 under growth-inhibitory conditions in squamous carcinoma cells. Mol. Endocrinol. 2001, 15, 1127-1139.

77. Chiang, K.C.; Yeh, C.N.; Chen, S.C.; Shen, S.C.; Hsu, J.T.; Yeh, T.S.; Pang, J.H.; Su, L.J.; Takano, M.; Kittaka, A.; et al. MART-10, a new generation of vitamin D analog, is more potent than 1alpha,25-dihydroxyvitamin $\mathrm{D}(3)$ in inhibiting cell proliferation and inducing apoptosis in ER+ MCF-7 breast cancer cells. Evid. Based Complement. Alternat. Med. 2012, 2012, 310872.

78. Baudet, C.; Chevalier, G.; Chassevent, A.; Canova, C.; Filmon, R.; Larra, F.; Brachet, P.; Wion, D. 1,25-Dihydroxyvitamin D3 induces programmed cell death in a rat glioma cell line. J. Neurosci. Res. 1996, 46, 540-550.

79. Bao, B.Y.; Hu, Y.C.; Ting, H.J.; Lee, Y.F. Androgen signaling is required for the vitamin D-mediated growth inhibition in human prostate cancer cells. Oncogene 2004, 23, 3350-3360.

80. Valko, M.; Rhodes, C.J.; Moncol, J.; Izakovic, M.; Mazur, M. Free radicals, metals and antioxidants in oxidative stress-induced cancer. Chem. Biol. Interact. 2006, 160, 1-40.

81. Valko, M.; Leibfritz, D.; Moncol, J.; Cronin, M.T.; Mazur, M.; Telser, J. Free radicals and antioxidants in normal physiological functions and human disease. Int. J. Biochem. Cell. Biol. 2007, 39, 44-84.

82. Losso, J.N.; Bawadi, H.A. Hypoxia inducible factor pathways as targets for functional foods. J. Agric. Food Chem. 2005, 53, 3751-3768.

83. Peehl, D.M.; Shinghal, R.; Nonn, L.; Seto, E.; Krishnan, A.V.; Brooks, J.D.; Feldman, D. Molecular activity of 1,25-dihydroxyvitamin D3 in primary cultures of human prostatic epithelial cells revealed by cDNA microarray analysis. J. Steroid Biochem. Mol. Biol. 2004, 92, 131-141.

84. Bao, B.Y.; Ting, H.J.; Hsu, J.W.; Lee, Y.F. Protective role of 1 alpha, 25-dihydroxyvitamin D3 against oxidative stress in nonmalignant human prostate epithelial cells. Int. J. Cancer 2008, 122, 2699-2706. 
85. Fleet, J.C.; DeSmet, M.; Johnson, R.; Li, Y. Vitamin D and cancer: A review of molecular mechanisms. Biochem. J. 2012, 441, 61-76.

86. Ben-Shoshan, M.; Amir, S.; Dang, D.T.; Dang, L.H.; Weisman, Y.; Mabjeesh, N.J. 1alpha,25Dihydroxyvitamin D3 (calcitriol) inhibits hypoxia-inducible factor-1/vascular endothelial growth factor pathway in human cancer cells. Mol. Cancer Ther. 2007, 6, 1433-1439.

87. Chung, I.; Han, G.; Seshadri, M.; Gillard, B.M.; Yu, W.D.; Foster, B.A.; Trump, D.L.; Johnson, C.S. Role of vitamin D receptor in the antiproliferative effects of calcitriol in tumor-derived endothelial cells and tumor angiogenesis in vivo. Cancer Res. 2009, 69, 967-975.

88. Dormoy, V.; Beraud, C.; Lindner, V.; Coquard, C.; Barthelmebs, M.; Brasse, D.; Jacqmin, D.; Lang, H.; Massfelder, T. Vitamin D3 triggers antitumor activity through targeting hedgehog signaling in human renal cell carcinoma. Carcinogenesis 2012, 33, 2084-2093.

89. $\mathrm{Yu}, \mathrm{H}$.; Rohan, T. Role of the insulin-like growth factor family in cancer development and progression. J. Natl. Cancer Inst. 2000, 92, 1472-1489.

90. Figueroa, J.A.; de Raad, S.; Tadlock, L.; Speights, V.O.; Rinehart, J.J. Differential expression of insulin-like growth factor binding proteins in high versus low gleason score prostate cancer. J. Urol. 1998, 159, 1379-1383.

91. Kriebitzsch, C.; Verlinden, L.; Eelen, G.; Tan, B.K.; van Camp, M.; Bouillon, R.; Verstuyf, A. The impact of $1,25(\mathrm{OH}) 2 \mathrm{D} 3$ and its structural analogs on gene expression in cancer cellsA microarray approach. Anticancer Res. 2009, 29, 3471-3483.

92. Krishnan, A.V.; Shinghal, R.; Raghavachari, N.; Brooks, J.D.; Peehl, D.M.; Feldman, D. Analysis of vitamin D-regulated gene expression in LNCaP human prostate cancer cells using cDNA microarrays. Prostate 2004, 59, 243-251.

93. Lee, H.J.; Liu, H.; Goodman, C.; Ji, Y.; Maehr, H.; Uskokovic, M.; Notterman, D.; Reiss, M.; Suh, N. Gene expression profiling changes induced by a novel gemini vitamin D derivative during the progression of breast cancer. Biochem. Pharmacol. 2006, 72, 332-343.

94. Swami, S.; Raghavachari, N.; Muller, U.R.; Bao, Y.P.; Feldman, D. Vitamin D growth inhibition of breast cancer cells: Gene expression patterns assessed by cDNA microarray. Breast Cancer Res. Treat. 2003, 80, 49-62.

95. Chen, A.; Davis, B.H.; Sitrin, M.D.; Brasitus, T.A.; Bissonnette, M. Transforming growth factor-beta 1 signaling contributes to caco-2 cell growth inhibition induced by $1,25(\mathrm{OH})(2) \mathrm{D}(3)$. Am. J. Physiol. Gastrointest Liver Physiol. 2002, 283, G864-G874.

96. Tong, W.M.; Hofer, H.; Ellinger, A.; Peterlik, M.; Cross, H.S. Mechanism of antimitogenic action of vitamin D in human colon carcinoma cells: Relevance for suppression of epidermal growth factor-stimulated cell growth. Oncol. Res. 1999, 11, 77-84.

97. Yanagisawa, J.; Yanagi, Y.; Masuhiro, Y.; Suzawa, M.; Watanabe, M.; Kashiwagi, K.; Toriyabe, T.; Kawabata, M.; Miyazono, K.; Kato, S. Convergence of transforming growth factor-beta and vitamin D signaling pathways on SMAD transcriptional coactivators. Science 1999, 283, $1317-1321$.

98. Schlange, T.; Matsuda, Y.; Lienhard, S.; Huber, A.; Hynes, N.E. Autocrine WNT signaling contributes to breast cancer cell proliferation via the canonical WNT pathway and EGFR transactivation. Breast Cancer Res. 2007, 9, R63. 
99. Rosenbluh, J.; Nijhawan, D.; Cox, A.G.; Li, X.; Neal, J.T.; Schafer, E.J.; Zack, T.I.; Wang, X.; Tsherniak, A.; Schinzel, A.C.; et al. Beta-Catenin-Driven cancers require a yap1 transcriptional complex for survival and tumorigenesis. Cell 2012, 151, 1457-1473.

100. Behrens, J. Everything you would like to know about wnt signaling. Sci. Signal. 2013, 6, pe17.

101. Vadlakonda, L.; Pasupuleti, M.; Pallu, R. Role of pi3k-akt-mtor and wnt signaling pathways in transition of g1-s phase of cell cycle in cancer cells. Front. Oncol. 2013, 3, 85.

102. Brabletz, T.; Jung, A.; Dag, S.; Hlubek, F.; Kirchner, T. Beta-Catenin regulates the expression of the matrix metalloproteinase-7 in human colorectal cancer. Am. J. Pathol. 1999, 155, 1033-1038.

103. Nusse, R.; Varmus, H.E. Wnt genes. Cell 1992, 69, 1073-1087.

104. Nusse, R. The wnt gene family in tumorigenesis and in normal development. J. Steroid Biochem. Mol. Biol. 1992, 43, 9-12.

105. Nusse, R. Wnt signaling and stem cell control. Cell Res. 2008, 18, 523-527.

106. Jamora, C.; DasGupta, R.; Kocieniewski, P.; Fuchs, E. Links between signal transduction, transcription and adhesion in epithelial bud development. Nature 2003, 422, 317-322.

107. Kovalenko, P.L.; Zhang, Z.; Cui, M.; Clinton, S.K.; Fleet, J.C. 1,25 dihydroxyvitamin d-mediated orchestration of anticancer, transcript-level effects in the immortalized, non-transformed prostate epithelial cell line, rwpe1. BMC Genomics 2010, 11, 26.

108. Palmer, H.G.; Gonzalez-Sancho, J.M.; Espada, J.; Berciano, M.T.; Puig, I.; Baulida, J.; Quintanilla, M.; Cano, A.; de Herreros, A.G.; Lafarga, M.; et al. Vitamin d(3) promotes the differentiation of colon carcinoma cells by the induction of e-cadherin and the inhibition of beta-catenin signaling. J. Cell Biol. 2001, 154, 369-387.

109. Pendas-Franco, N.; Aguilera, O.; Pereira, F.; Gonzalez-Sancho, J.M.; Munoz, A. Vitamin d and wnt/beta-catenin pathway in colon cancer: Role and regulation of dickkopf genes. Anticancer Res. 2008, 28, 2613-2623.

110. Beildeck, M.E.; Islam, M.; Shah, S.; Welsh, J.; Byers, S.W. Control of tcf-4 expression by vdr and vitamin $\mathrm{d}$ in the mouse mammary gland and colorectal cancer cell lines. PLoS One 2009, 4, e7872.

111. Rohan, J.N.; Weigel, N.L. 1alpha,25-dihydroxyvitamin d3 reduces c-myc expression, inhibiting proliferation and causing g1 accumulation in c4-2 prostate cancer cells. Endocrinology 2009, 150, 2046-2054.

112. Rawson, J.B.; Sun, Z.; Dicks, E.; Daftary, D.; Parfrey, P.S.; Green, R.C.; Gallinger, S.; McLaughlin, J.R.; Wang, P.P.; Knight, J.A.; et al. Vitamin d intake is negatively associated with promoter methylation of the wnt antagonist gene dkk1 in a large group of colorectal cancer patients. Nutr. Cancer 2012, 64, 919-928.

113. Aguilera, O.; Pena, C.; Garcia, J.M.; Larriba, M.J.; Ordonez-Moran, P.; Navarro, D.; Barbachano, A.; Lopez de Silanes, I.; Ballestar, E.; Fraga, M.F.; et al. The wnt antagonist dickkopf-1 gene is induced by 1alpha,25-dihydroxyvitamin $\mathrm{d} 3$ associated to the differentiation of human colon cancer cells. Carcinogenesis 2007, 28, 1877-1884.

114. Villaggio, B.; Soldano, S.; Cutolo, M. 1,25-Dihydroxyvitamin D3 downregulates aromatase expression and inflammatory cytokines in human macrophages. Clin. Exp. Rheumatol. 2012, 30, 934-938. 
115. Kaler, P.; Augenlicht, L.; Klampfer, L. Macrophage-derived il-1beta stimulates wnt signaling and growth of colon cancer cells: A crosstalk interrupted by vitamin d3. Oncogene 2009, 28, 3892-3902.

116. Bao, B.Y.; Yao, J.; Lee, Y.F. 1alpha,25-Dihydroxyvitamin d3 suppresses interleukin-8-mediated prostate cancer cell angiogenesis. Carcinogenesis 2006, 27, 1883-1893.

117. Tse, A.K.; Zhu, G.Y.; Wan, C.K.; Shen, X.L.; Yu, Z.L.; Fong, W.F. 1alpha,25-Dihydroxyvitamin d3 inhibits transcriptional potential of nuclear factor kappa $b$ in breast cancer cells. Mol. Immunol. 2010, 47, 1728-1738.

118. Hoyer-Hansen, M.; Jaattela, M. Autophagy: An emerging target for cancer therapy. Autophagy 2008, 4, 574-580.

119. Bristol, M.L.; Di, X.; Beckman, M.J.; Wilson, E.N.; Henderson, S.C.; Maiti, A.; Fan, Z.; Gewirtz, D.A. Dual functions of autophagy in the response of breast tumor cells to radiation: Cytoprotective autophagy with radiation alone and cytotoxic autophagy in radiosensitization by vitamin d 3. Autophagy 2012, 8, 739-753.

120. Mathew, R.; Kongara, S.; Beaudoin, B.; Karp, C.M.; Bray, K.; Degenhardt, K.; Chen, G.; Jin, S.; White, E. Autophagy suppresses tumor progression by limiting chromosomal instability. Genes Dev. 2007, 21, 1367-1381.

121. Karantza-Wadsworth, V.; Patel, S.; Kravchuk, O.; Chen, G.; Mathew, R.; Jin, S.; White, E. Autophagy mitigates metabolic stress and genome damage in mammary tumorigenesis. Genes Dev. 2007, 21, 1621-1635.

122. Wang, J. Beclin 1 bridges autophagy, apoptosis and differentiation. Autophagy 2008, 4, 947-948.

123. Wang, J.; Lian, H.; Zhao, Y.; Kauss, M.A.; Spindel, S. Vitamin d3 induces autophagy of human myeloid leukemia cells. J. Biol. Chem. 2008, 283, 25596-25605.

124. Lozy, F.; Karantza, V. Autophagy and cancer cell metabolism. Semin. Cell Dev. Biol. 2012, 23, 395-401.

125. Kato, S.; Takeyama, K.; Kitanaka, S.; Murayama, A.; Sekine, K.; Yoshizawa, T. In vivo function of VDR in gene expression-VDR knock-out mice. J. Steroid Biochem. Mol. Biol. 1999, 69, 247-251.

126. Li, Y.C.; Pirro, A.E.; Amling, M.; Delling, G.; Baron, R.; Bronson, R.; Demay, M.B. Targeted ablation of the vitamin d receptor: An animal model of vitamin d-dependent rickets type ii with alopecia. Proc. Natl. Acad. Sci. USA 1997, 94, 9831-9835.

127. Nakagawa, K.; Kawaura, A.; Kato, S.; Takeda, E.; Okano, T. Metastatic growth of lung cancer cells is extremely reduced in vitamin d receptor knockout mice. J. Steroid Biochem. Mol. Biol. 2004, 89-90, 545-547.

128. Kallay, E.; Pietschmann, P.; Toyokuni, S.; Bajna, E.; Hahn, P.; Mazzucco, K.; Bieglmayer, C.; Kato, S.; Cross, H.S. Characterization of a vitamin d receptor knockout mouse as a model of colorectal hyperproliferation and DNA damage. Carcinogenesis 2001, 22, 1429-1435.

129. Kallay, E.; Bareis, P.; Bajna, E.; Kriwanek, S.; Bonner, E.; Toyokuni, S.; Cross, H.S. Vitamin d receptor activity and prevention of colonic hyperproliferation and oxidative stress. Food Chem. Toxicol. 2002, 40, 1191-1196.

130. Zinser, G.; Packman, K.; Welsh, J. Vitamin d(3) receptor ablation alters mammary gland morphogenesis. Development 2002, 129, 3067-3076. 
131. Mehta, R.G.; Moriarty, R.M.; Mehta, R.R.; Penmasta, R.; Lazzaro, G.; Constantinou, A.; Guo, L. Prevention of preneoplastic mammary lesion development by a novel vitamin $\mathrm{d}$ analogue, 1alpha-hydroxyvitamin d5. J. Natl. Cancer Inst. 1997, 89, 212-218.

132. Mehta, R.; Hawthorne, M.; Uselding, L.; Albinescu, D.; Moriarty, R.; Christov, K. Prevention of $\mathrm{N}$-methyl- $\mathrm{N}$-nitrosourea-induced mammary carcinogenesis in rats by 1alpha-hydroxyvitamin d(5). J. Natl. Cancer Inst. 2000, 92, 1836-1840.

133. Jacobson, E.A.; James, K.A.; Newmark, H.L.; Carroll, K.K. Effects of dietary fat, calcium, and vitamin $d$ on growth and mammary tumorigenesis induced by 7,12-dimethylbenz(a)anthracene in female sprague-dawley rats. Cancer Res. 1989, 49, 6300-6303.

134. VanWeelden, K.; Flanagan, L.; Binderup, L.; Tenniswood, M.; Welsh, J. Apoptotic regression of MCF-7 xenografts in nude mice treated with the vitamin d3 analog, Eb1089. Endocrinology 1998, 139, 2102-2110.

135. Welsh, J. Vitamin $d$ and breast cancer: Insights from animal models. Am. J. Clin. Nutr. 2004, 80, 1721S-1724S.

136. Zinser, G.M.; Welsh, J. Accelerated mammary gland development during pregnancy and delayed postlactational involution in vitamin d3 receptor null mice. Mol. Endocrinol. 2004, 18, 2208-2223.

137. Welsh, J. Cellular and molecular effects of vitamin d on carcinogenesis. Arch. Biochem. Biophys. 2012, 523, 107-114.

138. Xu, H.; McCann, M.; Zhang, Z.; Posner, G.H.; Bingham, V.; El-Tanani, M.; Campbell, F.C. Vitamin $\mathrm{d}$ receptor modulates the neoplastic phenotype through antagonistic growth regulatory signals. Mol. Carcinog. 2009, 48, 758-772.

139. Xu, H.; Posner, G.H.; Stevenson, M.; Campbell, F.C. Apc(min) modulation of vitamin d secosteroid growth control. Carcinogenesis 2010, 31, 1434-1441.

140. Xie, Z.; Komuves, L.; Yu, Q.C.; Elalieh, H.; Ng, D.C.; Leary, C.; Chang, S.; Crumrine, D.; Yoshizawa, T.; Kato, S.; et al. Lack of the vitamin $\mathrm{d}$ receptor is associated with reduced epidermal differentiation and hair follicle growth. J. Investig. Dermatol. 2002, 118, 11-16.

141. Zinser, G.M.; Sundberg, J.P.; Welsh, J. Vitamin d(3) receptor ablation sensitizes skin to chemically induced tumorigenesis. Carcinogenesis 2002, 23, 2103-2109.

142. Zinser, G.M.; Tribble, E.; Valrance, M.; Urben, C.M.; Knutson, J.C.; Mazess, R.B.; Strugnell, S.A.; Welsh, J. 1,24(s)-dihydroxyvitamin d2, an endogenous vitamin d2 metabolite, inhibits growth of breast cancer cells and tumors. Anticancer Res. 2005, 25, 235-241.

143. Mordan-McCombs, S.; Brown, T.; Wang, W.L.; Gaupel, A.C.; Welsh, J.; Tenniswood, M. Tumor progression in the lpb-tag transgenic model of prostate cancer is altered by vitamin $\mathrm{d}$ receptor and serum testosterone status. J. Steroid Biochem. Mol. Biol. 2010, 121, 368-371.

144. Garland, C.F.; Garland, F.C. Do sunlight and vitamin d reduce the likelihood of colon cancer? Int. J. Epidemiol. 1980, 9, 227-231.

145. Garland, F.C.; Garland, C.F.; Gorham, E.D.; Young, J.F. Geographic variation in breast cancer mortality in the united states: A hypothesis involving exposure to solar radiation. Prev. Med. 1990, 19, 614-622.

146. Lefkowitz, E.S.; Garland, C.F. Sunlight, vitamin d, and ovarian cancer mortality rates in US women. Int. J. Epidemiol. 1994, 23, 1133-1136. 
147. Grant, W.B. Ecological studies of the UVB-vitamin d-cancer hypothesis. Anticancer Res. 2012, $32,223-236$.

148. Grant, W.B. Update on evidence that support a role of solar ultraviolet-b irradiance in reducing cancer risk. Anti-Cancer Agents Med. Chem. 2013, 13, 140-146.

149. Grant, W.B.; Garland, C.F. The association of solar ultraviolet b (UVB) with reducing risk of cancer: Multifactorial ecologic analysis of geographic variation in age-adjusted cancer mortality rates. Anticancer Res. 2006, 26, 2687-2699.

150. Grant, W.B. An estimate of premature cancer mortality in the U.S. Due to inadequate doses of solar ultraviolet-b radiation. Cancer 2002, 94, 1867-1875.

151. Mizoue, T. Ecological study of solar radiation and cancer mortality in japan. Health Phys. 2004, $87,532-538$.

152. Boscoe, F.P.; Schymura, M.J. Solar ultraviolet-b exposure and cancer incidence and mortality in the united states, 1993-2002. BMC Cancer 2006, 6, 264.

153. Chen, W.; Clements, M.; Rahman, B.; Zhang, S.; Qiao, Y.; Armstrong, B.K. Relationship between cancer mortality/incidence and ambient ultraviolet b irradiance in china. Cancer Causes Control. 2010, 21, 1701-1709.

154. Lin, S.W.; Wheeler, D.C.; Park, Y.; Cahoon, E.K.; Hollenbeck, A.R.; Freedman, D.M.; Abnet, C.C. Prospective study of ultraviolet radiation exposure and risk of cancer in the united states. Int. J. Cancer 2012, 131, E1015-E1023.

155. Astbury, A. Non Uniformity in Cancer Mortality in the USA and Australia Appears to Share a Common Origin; TRIUMF: Vancouver, BC, USA, 2005.

156. Grant, W.B. Does solar ultraviolet irradiation affect cancer mortality rates in china? Asian Pac. J. Cancer Prev. 2007, 8, 236-242.

157. Grant, W.B. An ecologic study of cancer mortality rates in spain with respect to indices of solar UVB irradiance and smoking. Int. J. Cancer 2007, 120, 1123-1128.

158. Grant, W.B. An ecological study of cancer incidence and mortality rates in france with respect to latitude, an index for vitamin d production. Deramato-Endocrinology 2010, 2, 62-67.

159. Grant, W.B. An ecological study of cancer mortality rates in california, 1950-64, with respect to solar UVB and smoking indices. Dermato-Endocrinology 2012, 4, 176-182.

160. Lombardi, C.; Heck, J.E.; Cockburn, M.; Ritz, B. Solar UV radiation and cancer in young children. Cancer Epidemiol. Biomark. Prev. 2013, 22, 1118-1128.

161. Fioletov, V.E.; McArthur, L.J.; Mathews, T.W.; Marrett, L. Estimated ultraviolet exposure levels for a sufficient vitamin d status in north america. J. Photochem. Photobiol. B 2010, 100, 57-66.

162. Grant, W.B. Role of solar UVB irradiance and smoking in cancer as inferred from cancer incidence rates by occupation in nordic countries. Dermato-Endocrinology 2012, 4, 203-211.

163. Brittingham, A.; de la Cruz, G.P. Ancestry 2000. Census 2000 Brief ck2br-35; U.S. Dept. of Commerce: Washington, DC, USA, 2004.

164. Grant, W.B. A multicountry ecological study of risk-modifying factors for prostate cancer: Apolipoprotein e epsilon4 as a risk factor and cereals as a risk reduction factor. Anticancer Res. 2010, 30, 189-199.

165. Lehrer, S. Possible relationship of the apolipoprotein e (apoe) epsilon4 allele to prostate cancer. Br. J. Cancer 1998, 78, 1398. 
166. Grant, W.B. Relation between prediagnostic serum 25-hydroxyvitamin d level and incidence of breast, colorectal, and other cancers. J. Photochem. Photobiol. B 2010, 101, 130-136.

167. Devesa, S.S.; Grauman, D.J.; Blot, W.J.; Pennello, G.A.; Hoover, R.N.; Fraumeni, J.F.J. Atlas of Cancer Mortality in the United States, 1950-1994. In NIH Publication No. 99-4564; National Institute of Health: Rockville, MD, USA, 1999.

168. Grant, W.B. An ecological study of cancer mortality rates in the united states with respect to solar ultraviolet-b doses, smoking, alcohol consumption and urban/rural residence. Dermato-Endocrinology 2010, 2, 68-76.

169. Grant, W.B. Effect of interval between serum draw and follow-up period on relative risk of cancer incidence with respect to 25-hydroxyvitamin d level: Implications for meta-analyses and setting vitamin d guidelines. Dermato-Endocrinology 2011, 3, 199-204.

170. Grant, W.B. Effect of follow-up time on the relation between prediagnostic serum 25-hydroxyvitamin d and all-cause mortality rate. Dermato-Endocrinology 2012, 4, 198-202.

171. Giovannucci, E.; Liu, Y.; Rimm, E.B.; Hollis, B.W.; Fuchs, C.S.; Stampfer, M.J.; Willett, W.C. Prospective study of predictors of vitamin $\mathrm{d}$ status and cancer incidence and mortality in men. J. Natl. Cancer Inst. 2006, 98, 451-459.

172. Afzal, S.; Bojesen, S.E.; Nordestgaard, B.G. Low plasma 25-hydroxyvitamin d and risk of tobacco-related cancer. Clin. Chem. 2013, 59, 771-780.

173. Mondul, A.M.; Weinstein, S.J.; Mannisto, S.; Snyder, K.; Horst, R.L.; Virtamo, J.; Albanes, D. Serum vitamin d and risk of bladder cancer. Cancer Res. 2010, 70, 9218-9223.

174. Epstein, E.; Lindqvist, P.G.; Geppert, B.; Olsson, H. A population-based cohort study on sun habits and endometrial cancer. Br. J. Cancer 2009, 101, 537-540.

175. Orell-Kotikangas, H.; Schwab, U.; Osterlund, P.; Saarilahti, K.; Makitie, O.; Makitie, A.A. High prevalence of vitamin d insufficiency in patients with head and neck cancer at diagnosis. Head Neck 2012, 34, 1450-1455.

176. Kricker, A.; Armstrong, B.K.; Hughes, A.M.; Goumas, C.; Smedby, K.E.; Zheng, T.; Spinelli, J.J.; de Sanjose, S.; Hartge, P.; Melbye, M.; et al. Personal sun exposure and risk of non hodgkin lymphoma: A pooled analysis from the interlymph consortium. Int. J. Cancer 2008, 122, $144-154$.

177. Toriola, A.T.; Surcel, H.M.; Calypse, A.; Grankvist, K.; Luostarinen, T.; Lukanova, A.; Pukkala, E.; Lehtinen, M. Independent and joint effects of serum 25-hydroxyvitamin $\mathrm{d}$ and calcium on ovarian cancer risk: A prospective nested case-control study. Eur. J. Cancer 2010, 46, 2799-2805.

178. Wolpin, B.M.; Ng, K.; Bao, Y.; Kraft, P.; Stampfer, M.J.; Michaud, D.S.; Ma, J.; Buring, J.E.; Sesso, H.D.; Lee, I.M.; et al. Plasma 25-hydroxyvitamin d and risk of pancreatic cancer. Cancer Epidemiol. Biomark. Prev. 2012, 21, 82-91.

179. Joh, H.K.; Giovannucci, E.L.; Bertrand, K.A.; Lim, S.; Cho, E. Predicted plasma 25-hydroxyvitamin d and risk of renal cell cancer. J. Natl. Cancer Inst. 2013, 105, 726-732.

180. Roskies, M.; Dolev, Y.; Caglar, D.; Hier, M.P.; Mlynarek, A.; Majdan, A.; Payne, R.J. Vitamin d deficiency as a potentially modifiable risk factor for thyroid cancer. J. Otolaryngol. Head Neck Surg. 2012, 41, 160-163. 
181. Shimada, T.; Urakawa, I.; Isakova, T.; Yamazaki, Y.; Epstein, M.; Wesseling-Perry, K.; Wolf, M.; Salusky, I.B.; Juppner, H. Circulating fibroblast growth factor 23 in patients with end-stage renal disease treated by peritoneal dialysis is intact and biologically active. J. Clin. Endocrinol. Metab. 2010, 95, 578-585.

182. Oh, E.Y.; Ansell, C.; Nawaz, H.; Yang, C.H.; Wood, P.A.; Hrushesky, W.J. Global breast cancer seasonality. Breast Cancer Res. Treat. 2010, 123, 233-243.

183. Lappe, J.M.; Travers-Gustafson, D.; Davies, K.M.; Recker, R.R.; Heaney, R.P. Vitamin d and calcium supplementation reduces cancer risk: Results of a randomized trial. Am. J. Clin. Nutr. 2007, 85, 1586-1591.

184. Peterlik, M.; Grant, W.B.; Cross, H.S. Calcium, vitamin d and cancer. Anticancer Res. 2009, 29, 3687-3698.

185. Bolland, M.J.; Grey, A.; Gamble, G.D.; Reid, I.R. Calcium and vitamin d supplements and health outcomes: A reanalysis of the women's health initiative (whi) limited-access data set. Am. J. Clin. Nutr. 2011, 94, 1144-1149.

186. Garland, C.F.; French, C.B.; Baggerly, L.L.; Heaney, R.P. Vitamin d supplement doses and serum 25-hydroxyvitamin $\mathrm{d}$ in the range associated with cancer prevention. Anticancer Res. 2011, 31, 607-611.

187. Lappe, J.M.; Heaney, R.P. Why randomized controlled trials of calcium and vitamin d sometimes fail. Dermato-Endocrinology 2012, 4, 95-100.

188. Ng, K.; Meyerhardt, J.A.; Wu, K.; Feskanich, D.; Hollis, B.W.; Giovannucci, E.L.; Fuchs, C.S. Circulating 25-hydroxyvitamin d levels and survival in patients with colorectal cancer. J. Clin. Oncol. 2008, 26, 2984-2991.

189. Grant, W.B.; Peiris, A.N. Differences in vitamin d status may account for unexplained disparities in cancer survival rates between african and white americans. Dermato-Endocrinology 2012, 4, 85-94.

190. Ginde, A.A.; Liu, M.C.; Camargo, C.A., Jr. Demographic differences and trends of vitamin d insufficiency in the us population, 1988-2004. Arch. Intern. Med. 2009, 169, 626-632.

191. Hill, A.B. The environment and disease: Association or causation? Proc. R. Soc. Med. 1965, 58, 295-300.

192. Grant, W.B. How strong is the evidence that solar ultraviolet $b$ and vitamin $d$ reduce the risk of cancer? An examination using hill's criteria for causality. Dermato-Endocrinology 2009, 1, 17-24.

193. Mohr, S.B.; Gorham, E.D.; Alcaraz, J.E.; Kane, C.I.; Macera, C.A.; Parsons, J.K.; Wingard, D.L.; Garland, C.F. Does the evidence for an inverse relationship between serum vitamin d status and breast cancer risk satisfy the hill criteria? Dermato-Endocrinology 2012, 4, 152-157.

(C) 2013 by the authors; licensee MDPI, Basel, Switzerland. This article is an open access article distributed under the terms and conditions of the Creative Commons Attribution license (http://creativecommons.org/licenses/by/3.0/). 